This discussion paper is/has been under review for the journal Atmospheric Chemistry and Physics (ACP). Please refer to the corresponding final paper in ACP if available.

\title{
Methanol-CO correlations in Mexico City pollution outflow from aircraft and satellite during MILAGRO
}

Y. Xiao ${ }^{1}$, K. E. Cady-Pereira ${ }^{1}$, V. H. Payne ${ }^{1}$, D. B. Millet ${ }^{2}$, M. W. Shephard ${ }^{3}$, M. Luo ${ }^{4}$, M. Alvarado ${ }^{1}$, K. C. Wells ${ }^{2}$, E. C. Apel ${ }^{5}$, T. L. Campos ${ }^{5}$, H. B. Singh ${ }^{6}$, and G. W. Sachse ${ }^{7}$

${ }^{1}$ Atmospheric and Environmental Research, Inc., Lexington, Massachusetts, USA

${ }^{2}$ University of Minnesota, Department of Soil, Water and Climate, St. Paul, Minnesota, USA ${ }^{3}$ Atmospheric and Climate Applications (AC Apps), Inc., East Gwillimbury, Ontario, Canada ${ }^{4}$ Jet Propulsion Laboratory, California Institute of Technology, Pasadena, California, USA

${ }^{5}$ National Center for Atmospheric Research, Boulder, CO, USA

${ }^{6}$ NASA Ames Research Center, CA, USA

${ }^{7}$ NASA Langley Research Center, VA, USA

Received: 19 December 2011 - Accepted: 18 January 2012 - Published: 22 February 2012 Correspondence to: Y. Xiao (yxiao@aer.com)

Published by Copernicus Publications on behalf of the European Geosciences Union.

Methanol-CO correlations in Mexico City pollution outflow

Y. Xiao et al.

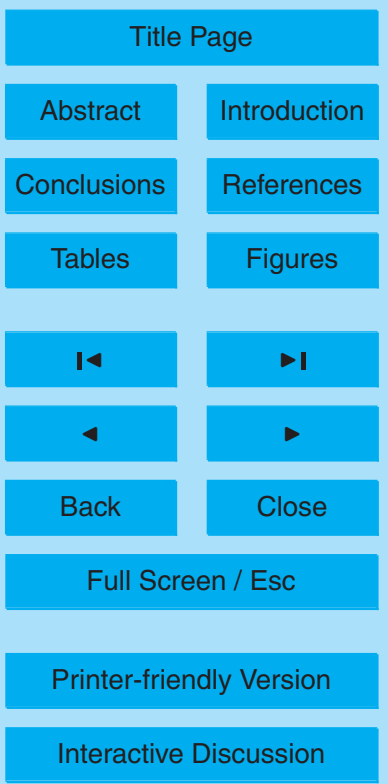




\section{Abstract}

The correlation between methanol $\left(\mathrm{CH}_{3} \mathrm{OH}\right)$ and carbon monoxide $(\mathrm{CO})$ is of particular interest for characterizing biogenic and anthropogenic emission sources of $\mathrm{CH}_{3} \mathrm{OH}$ and other chemical species. Here, the $\mathrm{CH}_{3} \mathrm{OH} / \mathrm{CO}$ enhancement ratio $\left(\Delta \mathrm{CH}_{3} \mathrm{OH} / \Delta \mathrm{CO}\right)$ in 5 the lower to middle troposphere is examined using coincident $\mathrm{CH}_{3} \mathrm{OH}$ and $\mathrm{CO}$ observations from aircraft (NCAR C-130 and NASA DC-8) and from the Tropospheric Emission Spectrometer (TES) satellite during the MegaCity Initiative: Local and Global Research Observations (MILAGRO) in the Mexico City region in March 2006. $\Delta \mathrm{CH}_{3} \mathrm{OH} / \Delta \mathrm{CO}$ ratios from the two in-situ aircraft measurements are far higher than previously reported $\mathrm{CH}_{3} \mathrm{OH}$ emission ratios relative to $\mathrm{CO}$ from $\mathrm{US}$ cities. This may reflect combustion of different fuel types in this area, and possibly photochemical production of $\mathrm{CH}_{3} \mathrm{OH}$ in Mexico City outflow. TES $\mathrm{CH}_{3} \mathrm{OH}$ and $\mathrm{CO}$ retrievals over the MILAGRO domain show relatively high sensitivity in the $600-800 \mathrm{hPa}$ range, associated with Mexico City pollution outflow. The TES derived $\Delta \mathrm{CH}_{3} \mathrm{OH} / \Delta \mathrm{CO}$ ratios during MILAGRO are 18$24 \mathrm{pptppb}^{-1}$, which are similar to those observed from the DC-8 (26-39 ppt ppb $\left.{ }^{-1}\right)$, but lower than the $\mathrm{C}-130$ observations $\left(41-55 \mathrm{pptppb}^{-1}\right)$. Differences between the $\Delta \mathrm{CH}_{3} \mathrm{OH} / \Delta \mathrm{CO}$ ratios measured aboard the two aircraft preclude an absolute validation of the TES-derived ratios for this dataset. The $\Delta \mathrm{CH}_{3} \mathrm{OH} / \Delta \mathrm{CO}$ ratios observed from TES over this domain reflect bulk enhancements of $\mathrm{CH}_{3} \mathrm{OH}$ and $\mathrm{CO}$ in Mexico City outflow. Although the TES measurements are not expected to resolve small-scale variability in the $\Delta \mathrm{CH}_{3} \mathrm{OH} / \Delta \mathrm{CO}$ ratio downwind of the strong source region of Mexico City, it is demonstrated that TES can clearly distinguish differences in the $\Delta \mathrm{CH}_{3} \mathrm{OH} / \Delta \mathrm{CO}$ ratio due to different source categories of $\mathrm{CH}_{3} \mathrm{OH}$. An example of this is shown by contrasting measurements over Mexico City (strong anthropogenic emissions) with those over the Amazon Basin (strong biogenic emissions). The results from this case study show the potential to gain insight into global sources of $\mathrm{CH}_{3} \mathrm{OH}$ and related species from satellite observations, especially for regions and time periods where no in situ measurements are available.

\section{Methanol-CO correlations in Mexico City pollution outflow}

Y. Xiao et al.

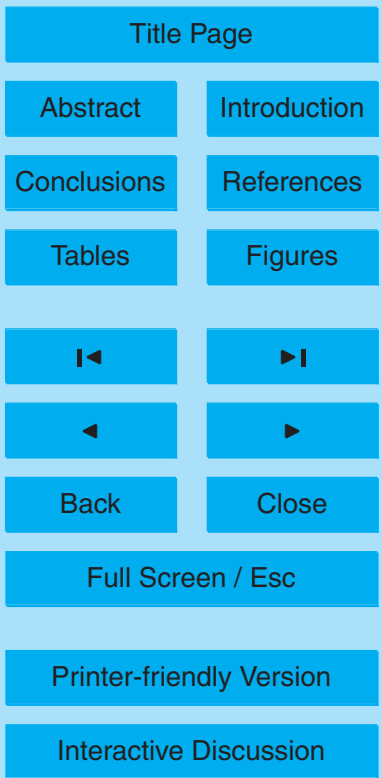




\section{Introduction}

Methanol $\left(\mathrm{CH}_{3} \mathrm{OH}\right)$ is one of the most abundant volatile organic compounds (VOCs). It is a significant source of tropospheric carbon monoxide (CO) and formaldehyde $\left(\mathrm{CH}_{2} \mathrm{O}\right)$ (Duncan et al., 2007; Millet et al., 2005; $\mathrm{Hu}$ et al., 2011). $\mathrm{CH}_{3} \mathrm{OH}$ can also 5 have an important influence on air quality in and around polluted urban areas (Molina et al., 2010). $\mathrm{CH}_{3} \mathrm{OH}$ may also contribute to particulate pollution (Blando and Turpin, 2000). The first global detection of methanol was made by Singh et al. (1995). Globally the major sources of $\mathrm{CH}_{3} \mathrm{OH}$ are biogenic processes with $~ 50 \%-80 \%$ of the estimated emissions involving plant growth (Harley et al., 2007; Karl et al., 2003) and, to a lesser extent, plant decay (Warneke et al., 1999). Other sources include biomass burning (Paton-Walsh et al., 2008; Dufour et al., 2006), anthropogenic sources from vehicles and industrial activities (de Gouw et al., 2005, 2009), as well as oxidation of methane and other volatile organic compounds (Tyndall et al., 2001; Madronich and Calvert, 1990). Although these other sources are much less important than the biogenic source 15 on a global scale, they can be responsible for large $\mathrm{CH}_{3} \mathrm{OH}$ enhancements on regional or continental scales. The main sink of $\mathrm{CH}_{3} \mathrm{OH}$ is oxidation by $\mathrm{OH}$ (Heikes et al., 2002). Dry and wet deposition to the surface constitutes a minor sink (Karl et al., 2010). The resulting overall atmospheric lifetime of $\mathrm{CH}_{3} \mathrm{OH}$ is approximately 5-10 days (Jacob et al., 2005).

20 Estimates of the source strength, seasonality, and spatial distribution of $\mathrm{CH}_{3} \mathrm{OH}$ in the atmosphere have previously been obtained from field measurements (e.g. Heikes et al., 2002; Singh et al., 2000), chemical transport modeling in combination with ground and airborne measurements of $\mathrm{CH}_{3} \mathrm{OH}$ (e.g. Millet et al., 2008; Jacob et al., 2005; Tie et al., 2003; Galbally and Kirstine, 2002), and from remotely sensed measurements from ground-based infrared spectrometers (e.g. Rinsland et al., 2009; Paton-Walsh et al., 2008). These studies have provided much-needed insight into $\mathrm{CH}_{3} \mathrm{OH}$ sources and atmospheric abundance. However, large uncertainties persist in terms of $\mathrm{CH}_{3} \mathrm{OH}$ source magnitudes, seasonality, and its spatial distribution in the atmosphere.

\section{Methanol-CO correlations in Mexico City pollution outflow}

Y. Xiao et al.

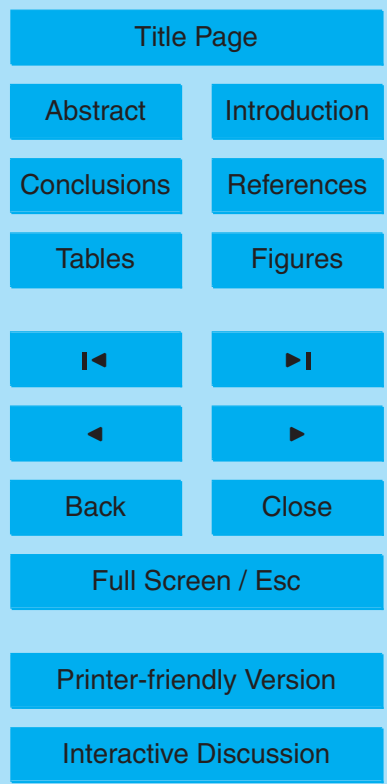


Satellite measurements offer the advantage of high spatial and temporal coverage, albeit with lower resolution than in situ observations. For example, $\mathrm{CH}_{3} \mathrm{OH}$ has been measured in biomass burning plumes in the upper troposphere from the Atmospheric Chemistry Experiment Fourier Transform Spectrometer (ACE-FTS), a limb-viewing in5 strument with relatively high vertical resolution and sensitivity to minor trace gases (Coheur et al., 2007; Dufour et al., 2006). More recently, it has been shown that nadir instruments can measure enhanced $\mathrm{CH}_{3} \mathrm{OH}$ in the lower troposphere. $\mathrm{CH}_{3} \mathrm{OH}$ retrievals have been performed using data from the Tropospheric Emission Spectrometer (TES) on the NASA Aura satellite (Cady-Pereira et al., 2012; Beer et al., 2008) and from the 10 Infrared Atmospheric Sounding Instrument (IASI) onboard the polar-orbiting MetOpA satellite (Razavi et al., 2011). In addition, TES and IASI observations have been employed to better constrain the seasonality of methanol emissions from northern midlatitude ecosystems (Wells et al., 2012) and to constrain biogenic and biomass burning emissions of methanol (Stavrakou et al., 2011). Both TES and IASI use the same spec15 tral region (centered at $1033 \mathrm{~cm}^{-1}$ ) for $\mathrm{CH}_{3} \mathrm{OH}$ retrieval. TES has high spectral resolution of $0.06 \mathrm{~cm}^{-1}$ at nadir providing the ability to distinguish the target species from interferences, while the IASI instrument has larger spatial coverage providing global coverage twice per day due to the wide scans across its track.

Constraints on the importance of various $\mathrm{CH}_{3} \mathrm{OH}$ source types can be gained by 20 examining the correlations between $\mathrm{CH}_{3} \mathrm{OH}$ and other measured species. The correlation between $\mathrm{CH}_{3} \mathrm{OH}$ and $\mathrm{CO}$ is of particular interest in source characterization (Warneke et al., 2007; de Gouw et al., 2005), and simultaneous measurements of $\mathrm{CH}_{3} \mathrm{OH}$ and $\mathrm{CO}$ are available from the satellite instruments listed above. $\mathrm{CH}_{3} \mathrm{OH}$ and $\mathrm{CO}$ share common anthropogenic and biomass burning sources. However, biogenic ${ }_{25} \mathrm{CH}_{3} \mathrm{OH}$ emissions can modify the $\mathrm{CH}_{3} \mathrm{OH}-\mathrm{CO}$ ratio to varying degrees depending on their importance relative to combustion sources. In general, both molecules exhibit a similar vertical distribution since their sources are mainly at the surface, although both $\mathrm{CH}_{3} \mathrm{OH}$ and $\mathrm{CO}$ do have atmospheric sources from the oxidation of $\mathrm{CH}_{4}$ and other volatile organic compounds (Madronich and Calvert, 1990).

\section{ACPD}

$12,5705-5738,2012$

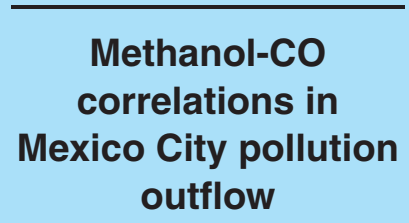

Y. Xiao et al.

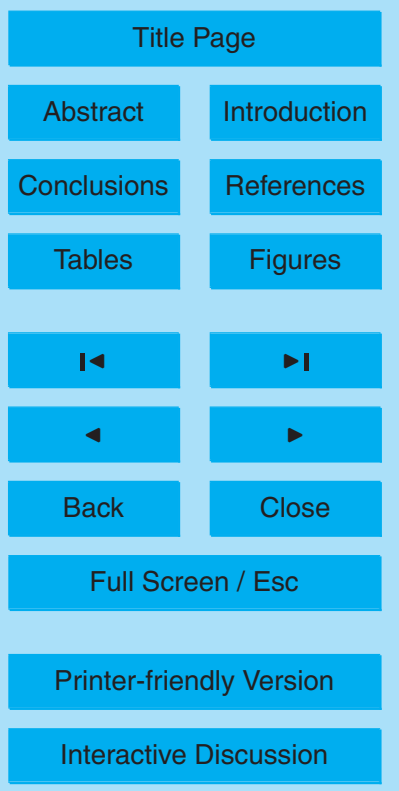

Interactive Discussion 
The Megacity Initiative: Local And Global Research Observations (MILAGRO) field campaign was conducted over the Mexico City Metropolitan Area (MCMA) and the Gulf of Mexico in March 2006, with the goal of examining the properties, evolution, and export of atmospheric emissions of trace gases and particles generated in the MCMA 5 and to evaluate the regional and global impacts of these emissions (Molina et al., 2010; Singh et al., 2009). Major sources of pollutants in the MCMA include motor vehicles (Apel et al., 2010), pervasive incomplete combustion of fossil fuels including Liquid Petroleum Gas (LPG) for low-temperature household cooking and heating (Blake and Rowland, 1995), and biomass burning (Crounse et al., 2009; Yokelson et al., 2007). 10 During MILAGRO, urban and regional measurements of a number of air pollutants were obtained by the National Center for Atmospheric Research (NCAR) C-130 and the National Aeronautics and Space Administration (NASA) DC-8 aircraft. In this analysis, we utilize MILAGRO aircraft measurements to determine correlations between $\mathrm{CH}_{3} \mathrm{OH}$ and $\mathrm{CO}$, as well as between $\mathrm{CH}_{3} \mathrm{OH}$ and other trace gas pollutants, in order to 15 qualitatively assess the influence of different sources on the $\mathrm{CH}_{3} \mathrm{OH}$ concentrations in the Mexico City outflow.

During MILAGRO TES also made a number of special observations over the MCMA. Retrievals of $\mathrm{CH}_{3} \mathrm{OH}$ and $\mathrm{CO}$ have been performed based on these observations. Direct comparisons of aircraft in situ profiles of $\mathrm{CH}_{3} \mathrm{OH}$ and $\mathrm{CO}$ with satellite retrievals during MILAGRO proved challenging as there were very few targeted profile underflights of the satellite track by either the C-130 or DC-8 aircraft over Mexico City, which limited sampling coincidence within reasonable spatial and temporal criteria. Instead, we have utilized $\mathrm{CH}_{3} \mathrm{OH}-\mathrm{CO}$ correlations to evaluate the ability of the satellite data to capture the important source information offered by aircraft measurements, with the goal of assessing whether such space-borne data can be reliably applied to other regions and time periods where no aircraft measurements are available. In addition, in order to further explore the utility of $\mathrm{CH}_{3} \mathrm{OH}-\mathrm{CO}$ correlations from TES, we have compared and contrasted satellite $\mathrm{CH}_{3} \mathrm{OH}-\mathrm{CO}$ correlations from MILAGRO (dominated by anthropogenic emissions - e.g. Molina et al., 2010) with those over the Amazon Basin

\section{ACPD}

12, 5705-5738, 2012

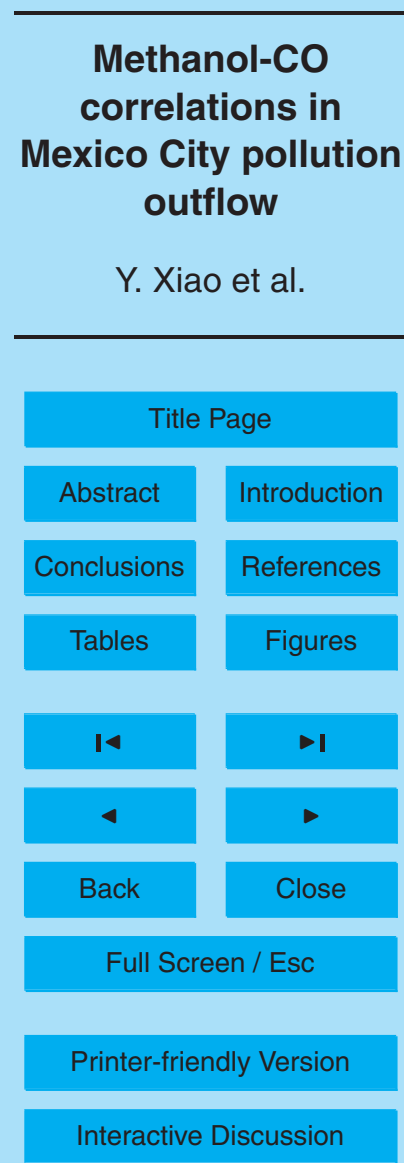

Interactive Discussion 
(dominated by biogenic emissions - e.g. Karl et al., 2007).

Descriptions of the aircraft and TES satellite measurements are provided in Sect. 2, and the analysis and results in Sect. 3.

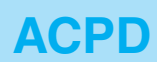

$12,5705-5738,2012$

\section{Measurements during MILAGRO}

\section{$5 \quad 2.1 \quad$ Aircraft measurements}

Figure 1 shows the aircraft flight tracks (along with TES footprint locations) during MILAGRO. All the data used in this work were collected within $12^{\circ} \mathrm{N}-30^{\circ} \mathrm{N}$ and $102^{\circ} \mathrm{W}-$ $90^{\circ} \mathrm{W}$, covering the region downwind of Mexico City and the northern part of the Gulf of Mexico. The MCMA $\left(19.43^{\circ} \mathrm{N}, 99.12^{\circ} \mathrm{W}\right)$ is located in the Valley of Mexico, a large basin $2.2 \mathrm{~km}$ a.s.l. The basin is surrounded on three sides by mountain ridges, with a broad opening to the north. The $\mathrm{C}-130$ flight tracks are closer than those of the DC-8 to the urban area of Mexico City, though some of the flights were designed to fly over remote regions either to detect long-range plume transport (more than $1000 \mathrm{~km}$ from Mexico City) or to measure biomass burning plumes. The DC-8 flight tracks cover a 15 larger geographical domain and the measurements are more representative of outflow at a distance from the sources.

Airborne measurements of $\mathrm{CH}_{3} \mathrm{OH}$ were made by the Total Organic Gas Analyzer (TOGA) (Apel et al., 2010) onboard the C-130, and the Peroxy Acetyl Nitrate/Aldehyde/Ketone Photo lonization Detector (PANAK) (Singh et al., 2004) onboard the DC-8. The reported $\mathrm{CH}_{3} \mathrm{OH}$ uncertainty for both aircraft instruments is $20 \%$ at $1 \sigma$ level. However, intercomparisons of TOGA (C-130) and PANAK (DC-8) measurements during MILAGRO have shown that the $\mathrm{CH}_{3} \mathrm{OH}$ values from the $\mathrm{C}-130$ are generally higher than those from the DC-8, by as much as a factor of 2 . This suggests a possible inconsistency in calibration between the $\mathrm{CH}_{3} \mathrm{OH}$ measurements onboard the two aircraft (Kleb et al., 2011, more details at http://www-air.larc.nasa.gov/missions/intex-b/ intexb-meas-comparison.htm). 
Volume mixing ratios of $\mathrm{CO}$ were measured by the Ultra-Violet Fluorescence (UVF) instrument on the C-130 (Holloway et al., 2000) with a quoted accuracy of $10 \%$, and by the Differential Absorption CO Measurement (DACOM) instrument (Sachse et al., 1987), a mid-IR diode laser spectrometer that measured $\mathrm{CO}, \mathrm{CH}_{4}$, and $\mathrm{N}_{2} \mathrm{O}$ on the 5 DC-8 aircraft. DACOM's quoted CO accuracy is $2 \%$ or 2 ppb. A suite of simultaneous observations of other related hydrocarbons on the $\mathrm{C}-130$ aircraft are also used in Sect. 3 for quantification of the source signature of $\mathrm{CH}_{3} \mathrm{OH}$. All those species were measured with an estimated accuracy of $\leq 20 \%$ (Singh et al., 2009). The MILAGRO data is supplied on a 1 min merge. However, the TOGA $\mathrm{CH}_{3} \mathrm{OH}$ measurements were

10 actually made with $2.8 \mathrm{~min}$ temporal resolution. Therefore, in this analysis we have further merged the data to 3 min intervals for instances where $\mathrm{CO}$ differs by more than $10 \mathrm{ppb}$ between time steps, but $\mathrm{CH}_{3} \mathrm{OH}$ values are constant. To reduce the influence of a small number of extreme outliers on the correlation analysis, we removed any data with $\mathrm{CO}$ concentrations greater than $500 \mathrm{ppb}$. These points were all located within $15300 \mathrm{~km}$ of the city center and comprised around $3 \%$ of the whole dataset. Any errors in the airborne $\mathrm{CH}_{3} \mathrm{OH}$ and $\mathrm{CO}$ measurements are assumed independent and not taken into account for the correlation analysis in Sect. 3.

\subsection{Satellite measurements from TES}

TES is a Fourier transform spectrometer flying on the NASA Aura satellite. The instru20 ment has high spectral resolution $\left(0.06 \mathrm{~cm}^{-1}\right)$ and a relatively small $(5 \times 8 \mathrm{~km})$ nadir footprint. The TES instrument measures radiances in the spectral range 650 to 3050 $\mathrm{cm}^{-1}$ (Beer et al., 2001) that are very stable (Conner et al., 2011) with good radiometric calibration and signal-to-noise (Shephard et al., 2008). These instrument characteristics provide TES with the capability to provide information on the vertical profiles 25 of temperature and numerous trace gases in the atmosphere. Profiles of temperature, water vapor $\left(\mathrm{H}_{2} \mathrm{O}\right.$ and $\left.\mathrm{HDO}\right)$, ozone $\left(\mathrm{O}_{3}\right), \mathrm{CO}$, methane $\left(\mathrm{CH}_{4}\right)$ and ammonia $\left(\mathrm{NH}_{3}\right)$ are currently produced routinely as operational products (Version 5$)$. Other trace gas products, including $\mathrm{CH}_{3} \mathrm{OH}$, are currently under development to be implemented

\section{Methanol-CO correlations in Mexico City pollution outflow}

Y. Xiao et al.

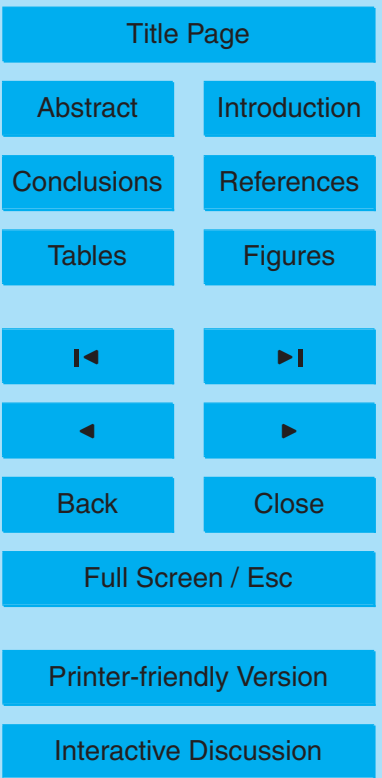


operationally. $\mathrm{CH}_{3} \mathrm{OH}$ is scheduled to be processed routinely as part of the TES Version 6 algorithm release.

TES conducted several special "step-and-stare" observations during the MILAGRO campaign. The TES nadir footprints in these observations are separated by $\sim 45 \mathrm{~km}$ 5 along the Aura ground track. The Aura overpass times for Mexico City are 01:45 and 13:45 LT.

The first space-based nadir retrievals of $\mathrm{CH}_{3} \mathrm{OH}$ were reported by Beer et al. (2008) for a limited number of TES special observations over Beijing (Northeast China), and San Diego (California, USA). Since then, the TES $\mathrm{CH}_{3} \mathrm{OH}$ retrieval approach has been 10 developed further and applied to larger volumes of data. The algorithm is based on an optimal estimation approach with a priori constraints. Details of the retrieval algorithm are reported in Cady-Pereira et al. (2012). The TES retrieval errors for $\mathrm{CH}_{3} \mathrm{OH}$ during MILAGRO range from $10 \%$ to $50 \%$, with larger relative errors for small retrieved $\mathrm{CH}_{3} \mathrm{OH}$ values. The TES retrievals have been validated against vertical profiles from 15 an ensemble of aircraft measurements over North America, where a 3-D chemical transport model was used as an intercomparison platform (Wells et al., 2012).

The TES operational CO product (Version 4) used in this analysis has been extensively validated against aircraft and other satellite measurements (Luo et al. 2007a, 2007b; Lopez et al., 2008), and showed a negative bias of $<10 \%$ in the lower and middle troposphere near Houston during INTEX-B and a positive bias of $\sim 5-10 \%$ in the tropics. Here we assume no correlation between the TES measurement errors for $\mathrm{CH}_{3} \mathrm{OH}$ and $\mathrm{CO}$ as they are in retrieved in different spectral bands. Any measurement errors should thus have little impact on the derived $\mathrm{CH}_{3} \mathrm{OH}-\mathrm{CO}$ enhancement ratios.

Figure 2 shows example averaging kernels for both $\mathrm{CH}_{3} \mathrm{OH}$ and $\mathrm{CO}$. Both species 25 have peak sensitivity in the $600-800 \mathrm{hPa}$ region. The TES $\mathrm{CO}$ and $\mathrm{CH}_{3} \mathrm{OH}$ retrievals contain a limited amount of vertical information, with $\sim 1.4$ degrees of freedom for signal (DOFS) for $\mathrm{CO}$ and typically $<1$ for $\mathrm{CH}_{3} \mathrm{OH}$. The vertical resolution for TES $\mathrm{CH}_{3} \mathrm{OH}$ and $\mathrm{CO}$ retrievals (defined as the full width at half maximum of the averaging kernels) is about $5-6 \mathrm{~km}$ in the troposphere.

\section{Methanol-CO correlations in Mexico City pollution outflow}

Y. Xiao et al.

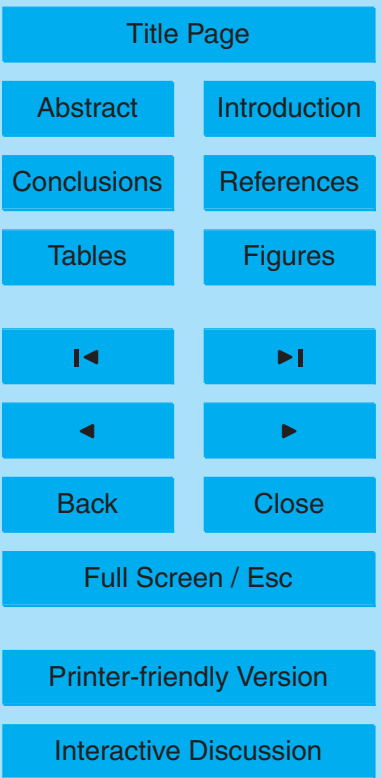


For both species, the number of vertical levels used in the retrieval is significantly greater than the number of DOFS for the measurement. Performing the retrieval in this way allows variations in vertical sensitivity between different profiles to be characterized via the averaging kernels. However, it also means that the details of the result on 5 any given retrieval level are highly sensitive to the shape of the chosen a priori profile. In order to mitigate this issue, a post-processing step is performed to map the result from the relatively fine retrieval grid to a representation that better reflects the information available in the measurement. The exact details of the mapping depend on the sensitivity (averaging kernels) for each individual measurement. For $\mathrm{CH}_{3} \mathrm{OH}$ with $\sim 1$ 10 (or less) DOFS, we report a single "representative volume mixing ratio" (RVMR) value. Further details of this approach can be found in Payne et al. (2009) and Shephard et al. (2011). The end result is that the RVMR value is less sensitive to assumptions about the a priori profile shape than a value at a single retrieval level would be. In order to assess the $\mathrm{CH}_{3} \mathrm{OH}-\mathrm{CO}$ correlations, the $\mathrm{CH}_{3} \mathrm{OH}$-sensitivity-based mapping was also applied to the $\mathrm{CO}$ retrieval in each case to produce a "pseudo CO RVMR". The same approach has been used to determine the emission ratio of ammonia and formic acid relative to $\mathrm{CO}$ using TES observations of boreal biomass plumes (Alvarado et al., 2011). In addition, an acceptance criterion of the $\mathrm{CH}_{3} \mathrm{OH} \mathrm{RVMR}>0.1 \mathrm{ppb}$ was applied to exclude those retrievals with very weak $\mathrm{CH}_{3} \mathrm{OH}$ signals in the TES spectra.

\section{Results}

\subsection{Source characterization of $\mathrm{CH}_{3} \mathrm{OH}$ in Mexico outflow}

Vertical profiles of $\mathrm{CH}_{3} \mathrm{OH}$ and $\mathrm{CO}$ mixing ratios from the DC-8 and $\mathrm{C}-130$ during MILAGRO (not shown) indicate outflow mainly at $600-800 \mathrm{hPa}$ near the city center, due to the high elevation of Mexico City. Downwind of the city center, enhanced $\mathrm{CH}_{3} \mathrm{OH}$ 25 and $\mathrm{CO}$ were detected up to $600 \mathrm{hPa}$ and down to the surface $(\sim 1000 \mathrm{hPa})$, with the

5713
$12,5705-5738,2012$

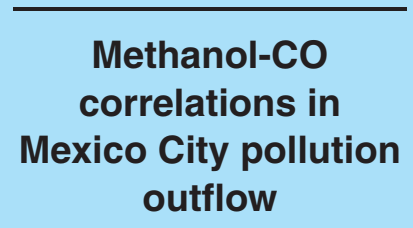

Y. Xiao et al.

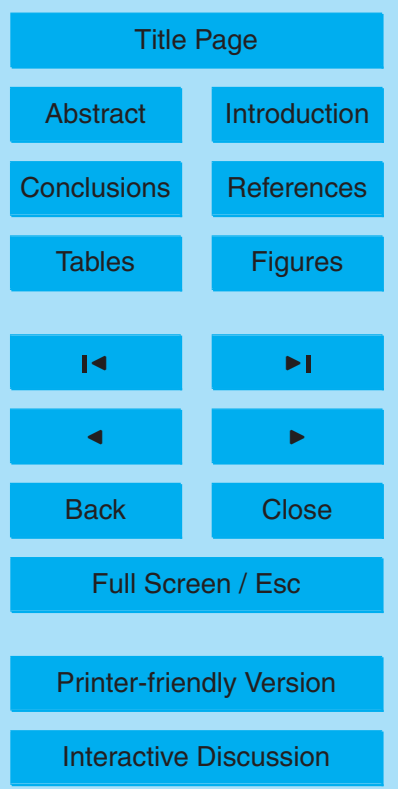

Interactive Discussion 
topography leading to a very efficient "air pump" exporting pollutants to the free troposphere (de Foy et al., 2006).

To examine the contributions of various source types to atmospheric $\mathrm{CH}_{3} \mathrm{OH}$ during MILAGRO, we examined a suite of gases indicative of anthropogenic, biogenic, 5 and biomass burning sources (the presumed sources of $\mathrm{CH}_{3} \mathrm{OH}$ ), and their correlations with $\mathrm{CH}_{3} \mathrm{OH}$. These indicator tracers include $\mathrm{CO}$, acetone $\left(\left(\mathrm{CH}_{3}\right)_{2} \mathrm{CO}\right)$, benzene $\left(\mathrm{C}_{6} \mathrm{H}_{6}\right)$, acetylene $\left(\mathrm{C}_{2} \mathrm{H}_{2}\right)$, hydrogen cyanide $(\mathrm{HCN})$ and acetonitrile $\left(\mathrm{CH}_{3} \mathrm{CN}\right)$. CO is a general tracer for combustion sources (fossil fuel, biofuel, and biomass burning). Acetone can be a good tracer of biogenic sources due to its relatively long lifetime (Singh 10 et al., 1995). There is also a large source of acetone from atmospheric oxidation of anthropogenic VOCs at northern midlatitudes (Fisher et al., 2012). Benzene can be regarded as an indicator of anthropogenic emissions involving solvent use, vehicle exhaust, and industrial processes (Karl et al., 2009). $\mathrm{C}_{2} \mathrm{H}_{2}$ is a relatively inert tracer and comes mostly from automobile exhaust (Harley et al., 1992). $\mathrm{HCN}$ and $\mathrm{CH}_{3} \mathrm{CN}$ are 15 tracers of biomass burning (Singh et al., 2010). Analysis of a subset of C-130 measurements near the MCMA during MILAGRO (Fig. 3) shows that $\mathrm{CH}_{3} \mathrm{OH}$ in this outflow region is correlated (1) strongly with $\mathrm{CO}$, acetone and benzene, (2) moderately with $\mathrm{C}_{2} \mathrm{H}_{2}$, and (3) less with $\mathrm{HCN}$ and $\mathrm{CH}_{3} \mathrm{CN}$, suggesting that the main sources of $\mathrm{CH}_{3} \mathrm{OH}$ during MILAGRO were anthropogenic and biogenic in nature.

In addition to primary anthropogenic and biogenic sources, photochemical formation could be a contributor to $\mathrm{CH}_{3} \mathrm{OH}$ during MILAGRO. As an oxygenated $\mathrm{VOC}, \mathrm{CH}_{3} \mathrm{OH}$ is produced by reaction of the methylperoxy radical $\left(\mathrm{CH}_{3} \mathrm{O}_{2}\right)$ with itself and with other organic peroxy radicals $\left(\mathrm{RO}_{2}\right)$ (Tyndall et al., 2001; Madronich and Calvert, 1990). In general, reactions involving $\mathrm{CH}_{3} \mathrm{O}_{2}$ and $\mathrm{RO}_{2}$ are not expected to be a large source of $\mathrm{CH}_{3} \mathrm{OH}$ in urban environments under high $\mathrm{NO}_{x}$ conditions (Molina et al., 2010). However, the very active photochemical environment and the extremely high $\mathrm{RO}_{2}$ concentrations in Mexico City could lead to reactions of $\mathrm{CH}_{3} \mathrm{O}_{2}$ with other peroxy radicals, potentially leading to significant $\mathrm{CH}_{3} \mathrm{OH}$ production in this specific region. In addition, Jacob et al. (2005) previously inferred a larger photochemical $\mathrm{CH}_{3} \mathrm{OH}$ source than

\section{Methanol-CO \\ correlations in \\ Mexico City pollution outflow}

Y. Xiao et al.

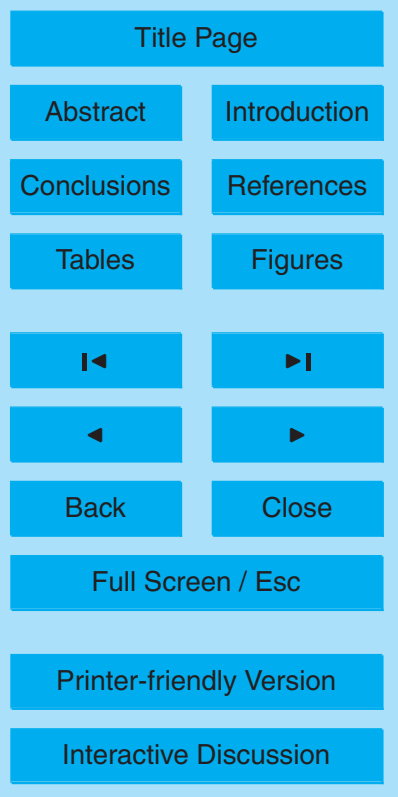

5714 
expected based on present understanding, though in the remote rather than urban polluted atmosphere. Any significant photochemical production of $\mathrm{CH}_{3} \mathrm{OH}$ during MILAGRO would have implications for the interpretation of $\mathrm{CH}_{3} \mathrm{OH}-\mathrm{CO}$ correlations, as will be discussed in Sect. 3.3.

\section{S.2 Spatial variability of $\mathrm{CH}_{3} \mathrm{OH}$ and $\mathrm{CO}$ concentrations around Mexico City}

Figure $4 \mathrm{a}, \mathrm{b}$ shows the variation in $\mathrm{CH}_{3} \mathrm{OH}$ and $\mathrm{CO}$ concentrations at $600-800 \mathrm{hPa}$ in the C-130 and DC-8 aircraft observations as a function of distance from the city center. The aircraft observations of both $\mathrm{CH}_{3} \mathrm{OH}$ and $\mathrm{CO}$ show a decreasing trend with increasing distance away from the urban source region, mainly due to dilution (mixing 10 with background air) and chemical decay.

Figure $4 \mathrm{c}$ shows the corresponding variation in the TES $\mathrm{CH}_{3} \mathrm{OH} \mathrm{RVMR}$ and pseudo CO RVMR. In contrast to the aircraft observations, the TES observations show no decreasing trend with distance downwind of the city. The limited spatial variability in TES CO for this area has been previously reported by Shim et al. (2009), who examined ${ }_{15} \mathrm{O}_{3}$ and $\mathrm{CO}$ from TES retrievals and MILAGRO aircraft measurements to characterize mega-city pollution outflow on a regional scale. They found that TES captures much of the spatial and day-to-day variability seen in the in situ data for $\mathrm{O}_{3}$, but not for $\mathrm{CO}$. In particular, TES does not clearly resolve the $\mathrm{CO}$ pollution over the Mexico City Basin. We explored a number of different possible reasons for this lack of spatial variability in 20 TES CO, including sampling issues, the vertical resolution of the TES measurements, and retrieval-related issues associated with the high altitude of Mexico City. Examination of these issues using $5 \mathrm{yr}$ of TES Version $4 \mathrm{CO}$ data over this region led to the conclusion that the handling of the TES Version $4 \mathrm{CO}$ prior constraints over regions with high surface elevation is an important contributor to the inadequate spatial variability in TES CO during MILAGRO. Points within $300 \mathrm{~km}$ of the city center mostly have high surface elevation, while areas farther from the center are closer to sea level. For the Version 5 (and previous versions) TES retrievals, the $\mathrm{CO}$ constraints are not shifted in altitude for high surface elevation regions. This leads to low values in the constraint

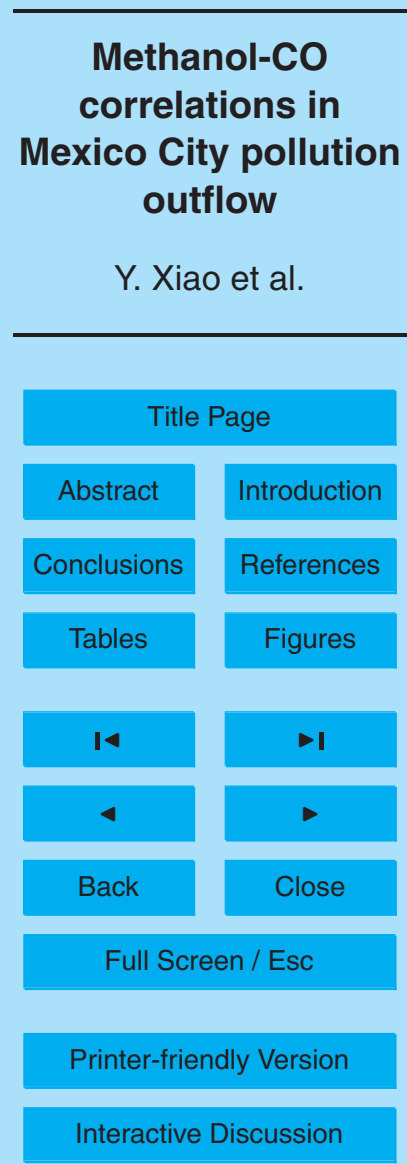


vector and tighter constraints from the prior than are desirable. Therefore, the TES CO values over Mexico City are generally constrained to lower values than they should be due to the a priori constraints. This issue will be considered in future TES algorithm updates. Note that this is less of an issue for the $\mathrm{O}_{3}$ retrievals, which are far more 5 loosely constrained in the upper troposphere than the $\mathrm{CO}$ retrievals. For the $\mathrm{CH}_{3} \mathrm{OH}$ retrievals the prior constraints are shifted vertically to account for variations in surface elevation (Cady-Pereira et al., 2012).

An additional contributor to the lack of spatial variability in $\mathrm{CH}_{3} \mathrm{OH}$ and $\mathrm{CO}$ during MILAGRO is the coarse vertical resolution of the measurements. In situ outflow profiles 10 measured during MILAGRO show concentrations that peak in a relatively narrow range. The TES $\mathrm{CH}_{3} \mathrm{OH}$ and $\mathrm{CO}$ retrievals are unable to distinguish between profiles with a sharp, strongly enhanced peak, and profiles where the trace gas enhancement has lower peak values but is spread over a wider vertical range. Therefore, TES does not reproduce the extreme high peak values observed by the aircraft, and would be expected to show lower average values than the plume-chasing aircraft, particularly in the region closest to the city center. However, this is not expected to bias the derived $\mathrm{CH}_{3} \mathrm{OH}-\mathrm{CO}$ correlation.

\subsection{Impact of vertical resolution of TES retrieval on the derived $\Delta \mathrm{CH}_{3} \mathrm{OH} / \Delta \mathrm{CO}$ ratio}

20 In this study the $\mathrm{CH}_{3} \mathrm{OH} / \mathrm{CO}$ enhancement ratio is defined as the slope of the regression between $\mathrm{CH}_{3} \mathrm{OH}$ and $\mathrm{CO}$, and is denoted as $\Delta \mathrm{CH}_{3} \mathrm{OH} / \Delta \mathrm{CO}$. The slope is calculated using the reduced major axis (RMA) method, which estimates the linear relationship between two variables by minimizing the residual variance in both $\mathrm{x}$ and $\mathrm{y}$ directions (Xiao et al., 2004; Hirsch and Gilroy, 1984). For the aircraft in-situ mea25 surements, it is straightforward to derive $\Delta \mathrm{CH}_{3} \mathrm{OH} / \Delta \mathrm{CO}$. For the TES observations, the $\Delta \mathrm{CH}_{3} \mathrm{OH} / \Delta \mathrm{CO}$ ratio is the regression slope between the $\mathrm{CH}_{3} \mathrm{OH} \mathrm{RVMR}$ and the pseudo CO RVMR (see Sect. 2.2).
ACPD

12, 5705-5738, 2012

\section{Methanol-CO \\ correlations in \\ Mexico City pollution \\ outflow}

Y. Xiao et al.

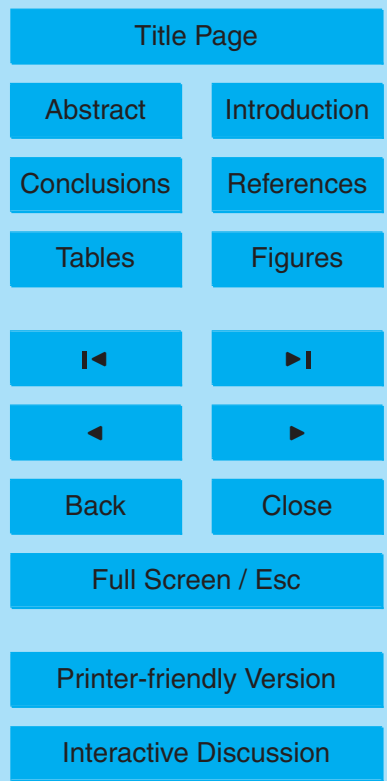


The vertical resolution of the TES measurement should be taken into consideration for the interpretation of the retrieved $\mathrm{CH}_{3} \mathrm{OH}$ and $\mathrm{CO}$ and the associated spatial variability in Mexico City outflow. Simulated retrievals are utilized to examine whether the coarse vertical resolution of TES $\mathrm{CH}_{3} \mathrm{OH}$ and $\mathrm{CO}$ observations would be expected to 5 affect the derived $\Delta \mathrm{CH}_{3} \mathrm{OH} / \Delta \mathrm{CO}$ ratios.

Starting with averaged $\mathrm{C}-130$ aircraft profiles of $\mathrm{CH}_{3} \mathrm{OH}$ and $\mathrm{CO}$ near the Mexico City center $(<300 \mathrm{~km})$, we constructed a base profile for each species, which was then scaled by factors of $1.25,1.5$ and 1.75 to create four profiles in total. These four profiles (shown as dashed lines in Fig. $5 a$ and b) were used as "truth" to generate four sets of 10 simulated TES radiances. Realistic noise was included in the simulated radiances. $\mathrm{CH}_{3} \mathrm{OH}$ retrievals were then performed on the simulated radiances. Simulated $\mathrm{CO}$ retrievals were generated from the assumed "true" profiles by applying the a priori and averaging kernel from a typical TES case with relatively strong sensitivity (from Version 4 of the TES operational algorithm). Retrieved profiles are shown as solid lines 15 in Fig. $5 \mathrm{a}$ and b. Thus, for each set of $\mathrm{CH}_{3} \mathrm{OH}$ and $\mathrm{CO}$ retrieved profiles, we have a pair of $\mathrm{CH}_{3} \mathrm{OH}$ and $\mathrm{CO}$ RVMRs, resulting in the TES $\Delta \mathrm{CH}_{3} \mathrm{OH} / \Delta \mathrm{CO}$ ratio shown in Fig. $5 \mathrm{~d}$. Despite the coarse vertical resolution of the TES measurements, TES is able to recover the true $\Delta \mathrm{CH}_{3} \mathrm{OH} / \Delta \mathrm{CO}$ ratio when both $\mathrm{CH}_{3} \mathrm{OH}$ and $\mathrm{CO}$ retrievals show relatively high sensitivity.

\subsection{Spatial variability in the $\Delta \mathrm{CH}_{3} \mathrm{OH} / \Delta \mathrm{CO}$ ratio}

In order to explore the utility of $\mathrm{CH}_{3} \mathrm{OH}-\mathrm{CO}$ correlations from TES observations, we evaluated the extent to which variability in the $\mathrm{CH}_{3} \mathrm{OH} / \mathrm{CO}$ enhancement ratio is captured by TES based on in-situ aircraft observations during MILAGRO. The $\Delta \mathrm{CH}_{3} \mathrm{OH} / \triangle \mathrm{CO}$ ratio observed by TES reflects the bulk enhancements of $\mathrm{CH}_{3} \mathrm{OH}$ 25 and $\mathrm{CO}$ in the Mexico City outflow, smoothed by the TES vertical sensitivity. For TES/aircraft comparisons of the $\Delta \mathrm{CH}_{3} \mathrm{OH} / \Delta \mathrm{CO}$ ratio, only aircraft data in the 600$800 \mathrm{hPa}$ range, the region where the TES $\mathrm{CH}_{3} \mathrm{OH}$ and $\mathrm{CO}$ retrievals have the greatest sensitivity, are used.

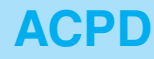

$12,5705-5738,2012$

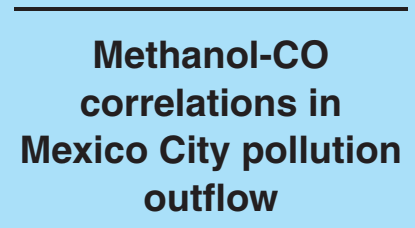

Y. Xiao et al.

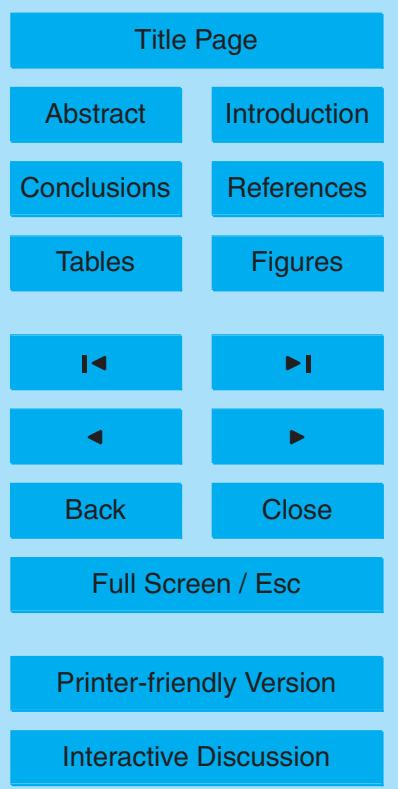

Interactive Discussion 
Figure 6a shows the $\mathrm{CH}_{3} \mathrm{OH}-\mathrm{CO}$ correlations from the two aircraft. In contrast with the $\mathrm{CH}_{3} \mathrm{OH}$ and $\mathrm{CO}$ concentrations themselves, $\Delta \mathrm{CH}_{3} \mathrm{OH} / \Delta \mathrm{CO}$ ratios for air masses with significant source influence vary little with geographical location. Instead, slightly higher ratios are seen outside the $300 \mathrm{~km}$ range as compared to within $300 \mathrm{~km}$ 5 around the city. This may be explained by photochemical production of $\mathrm{CH}_{3} \mathrm{OH}$. The $\Delta \mathrm{CH}_{3} \mathrm{OH} / \Delta \mathrm{CO}$ ratios based on the $\mathrm{C}-130$ aircraft measurements are $41-55 \mathrm{ppt} \mathrm{ppb}^{-1}$, while the DC-8 observations show much lower values of $26-39 \mathrm{ppt} \mathrm{ppb}^{-1}$. The different $\Delta \mathrm{CH}_{3} \mathrm{OH} / \Delta \mathrm{CO}$ ratios between the $\mathrm{C}-130$ and DC-8 measurements appear to reflect a calibration offset (see Sect. 2.1) rather than the different sampling strategy for the two aircraft (Singh et al., 2009), since the discrepancy persists regardless of the distance from the MCMA (Fig. 6a).

Figure $6 \mathrm{~b}$ shows the corresponding $\mathrm{CH}_{3} \mathrm{OH}-\mathrm{CO}$ correlations as measured by TES. As with the aircraft observations (Fig. 6a), TES $\Delta \mathrm{CH}_{3} \mathrm{OH} / \Delta \mathrm{CO}$ ratios display little variation with distance from the city center (ranging from 18 to $24 \mathrm{ppt} \mathrm{ppb}^{-1}$ ), and are closer to the values derived from the DC-8 measurements during MILAGRO than to those derived from the $\mathrm{C}-130$ measurements. Note that close to Mexico City center, we expect TES CO retrievals using the Version 4 algorithm to under-represent the true values due to the issues with the constraints discussed above. This particular issue should not be present in the TES $\mathrm{CH}_{3} \mathrm{OH}$ observations as our retrieval shifts the constraints. With more appropriate $\mathrm{CO}$ constraints, it is expected that the TES data will exhibit some spatial variation in the enhancement ratios, with slightly lower ratio values (increased CO values) closer to the city center, as seen in the aircraft data.

Any discrepancies between TES and aircraft ratios for the MILAGRO dataset may be due to aircraft instrument calibration issues, or to systematic errors in the TES re-

sults. Possible sources of systematic error in the TES retrievals include forward model errors (such as biases in spectroscopic line parameters or incorrect representation of interfering species), errors in the TES radiance calibration, and influence of the a priori assumptions in the retrieval (the effect of the a priori assumptions is mitigated, but not eliminated, by the RVMR representation). Given the present discrepancy between the

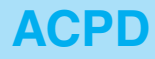

12, 5705-5738, 2012

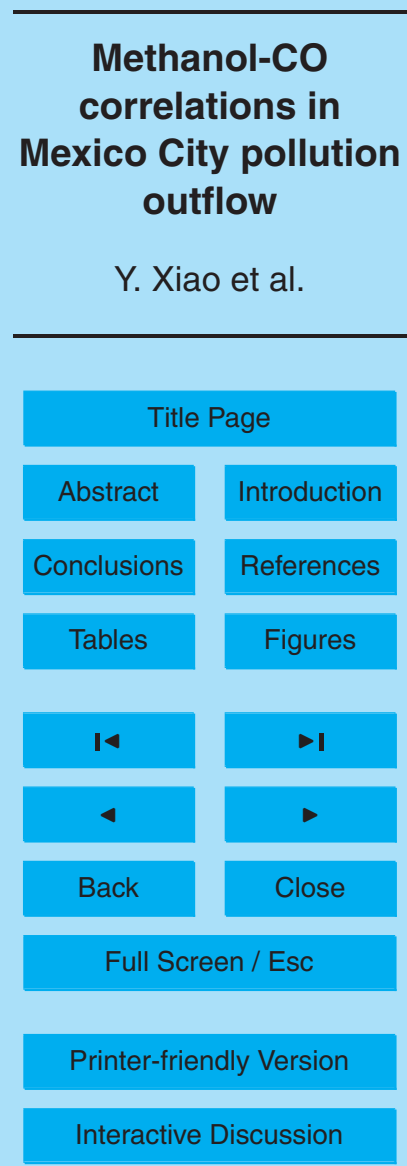

Interactive Discussion 
aircraft measurements of $\mathrm{CH}_{3} \mathrm{OH}$, it is difficult at this stage to use the aircraft observations as evaluation of the absolute TES enhancement ratios.

In contrast with Mexico City, a region dominated by strong anthropogenic emissions, we also examine the TES $\Delta \mathrm{CH}_{3} \mathrm{OH} / \Delta \mathrm{CO}$ ratios over the Amazon Basin, a region dom5 inated by biogenic emissions (with an additional biomass burning source contribution) (Karl et al., 2007). Similar to the MILAGRO domain the Amazon region exhibits elevated $\mathrm{CH}_{3} \mathrm{OH}$ values, which provides a relatively high signal-to-noise ratio for the TES observations. Figure 7 shows TES $\Delta \mathrm{CH}_{3} \mathrm{OH} / \Delta \mathrm{CO}$ ratios over the Amazon Basin during August-September of 2005. The ratio of $42 \pm 7 \mathrm{pptppb}^{-1}$ is a factor of 2 higher 10 than that observed near Mexico City during MILAGRO (18-24 ppt ppb ${ }^{-1}$ ). The significant ratio difference between Mexico City and the Amazon Basin indicates that the TES-derived $\Delta \mathrm{CH}_{3} \mathrm{OH} / \Delta \mathrm{CO}$ ratio has potential for differentiating source categories of $\mathrm{CH}_{3} \mathrm{OH}$ and other chemical species with multiple sources (e.g. $\mathrm{CO}_{2}$ ). With future work, the TES-derived ratio could be applied globally to other regions and time periods where 15 no in situ measurements are available.

It should be noted that connecting the observed $\Delta \mathrm{CH}_{3} \mathrm{OH} / \Delta \mathrm{CO}$ ratio from either aircraft or TES with the actual $\mathrm{CH}_{3} \mathrm{OH} / \mathrm{CO}$ emission ratio from "urban" sources in Mexico City is complicated, since the $\Delta \mathrm{CH}_{3} \mathrm{OH} / \Delta \mathrm{CO}$ ratio could have already been enhanced due to photochemical production of $\mathrm{CH}_{3} \mathrm{OH}$ even in the plumes thought to be "fresh". 20 Ground-based estimates of emission ratios tend to show lower values than the enhancement ratios measured aboard aircraft. For example, Bon et al. (2011) report $\mathrm{CH}_{3} \mathrm{OH} / \mathrm{CO}$ emission ratios of $2.1 \pm 0.5 \mathrm{ppt} \mathrm{ppb}^{-1}$ and $6.1 \pm 2.1 \mathrm{ppt} \mathrm{ppb}^{-1}$ from boundary layer observations at urban sites during MILAGRO. The complicated relationship between emission ratios at the source and enhancement ratios in plumes does not apply just too urban sources. For instance, Holzinger et al. (2005) observed relatively high $\mathrm{CH}_{3} \mathrm{OH}$ and acetone enhancements in fire plumes over the Mediterranean, and concluded that secondary production of these species must have taken place. Caution is therefore needed when interpreting enhancement ratios as opposed to emission ratios.

\section{Methanol-CO correlations in Mexico City pollution outflow}

Y. Xiao et al.

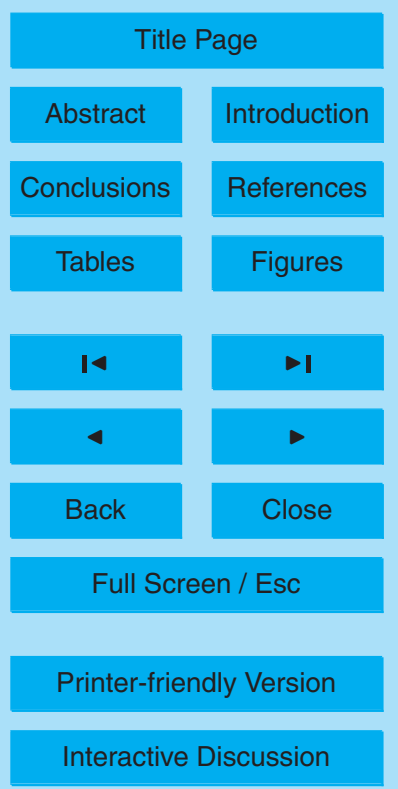

Interactive Discussion 


\section{5 $\Delta \mathrm{CH}_{3} \mathrm{OH} / \Delta \mathrm{CO}$ ratio from other campaigns}

The $\Delta \mathrm{CH}_{3} \mathrm{OH} / \Delta \mathrm{CO}$ ratios derived in this analysis from the $\mathrm{C}-130$ observations during MILAGRO (41-55 $\left.\mathrm{ppt} \mathrm{ppb}^{-1}\right)$ are significantly higher than ratios from other aircraft studies in US cities (Table 1). Singh et al. (2010) derived a ratio of $21.0 \pm 14.0 \mathrm{ppb} \mathrm{ppb}^{-1}$

5 in urban plumes mainly sampled over California. Warneke et al. (2007) derived a ratio of $9 \mathrm{pptppb}^{-1}$ in fresh New York City and Boston plumes in July and August of 2004, and $8.4 \mathrm{ppt} \mathrm{ppb}^{-1}$ from aircraft observations over the Los Angeles Basin in the spring of 2002. The ratios from the C-130 measurements during MILAGRO are also much higher than the ratios of $4-11$ ppt ppb ${ }^{-1}$ over Boulder, Colorado and Pittsburgh, Penn10 sylvania reported from ground-based winter measurements (Millet et al., 2005; Goldan et al., 1995).

To put these urban values into context, $\Delta \mathrm{CH}_{3} \mathrm{OH} / \Delta \mathrm{CO}$ ratios have also been reported for biomass burning plumes during the MILAGRO experiment. High ratios of 14-28 pptppb ${ }^{-1}$ were reported by Yokelson et al. (2009) based on aircraft measure15 ments of fresh plumes from fires in the Yucatan region of Mexico. Comparable ratios of 19-32 ppt ppb ${ }^{-1}$ can be derived from the data presented by Yokelson et al. (2011), who reported emission factors for 25 open fires based on airborne measurements during March 2006.

The aircraft $\Delta \mathrm{CH}_{3} \mathrm{OH} / \Delta \mathrm{CO}$ ratios from Mexico City are also much higher than 20 those reported from biomass burning at northern mid/high latitudes. Simpson et al. (2011) and Singh et al. (2010) derived mean ratios of $9.6 \pm 1.9 \mathrm{pptppb}^{-1}$, and $15.6 \pm 9.2 \mathrm{ppb} \mathrm{ppb}^{-1}$, respectively, in fresh Canadian fire plumes. De Gouw et al. (2006) derived a ratio of $10.8 \pm 4.4 \mathrm{ppt} \mathrm{ppb}^{-1}$ from aged fire plumes in Alaska and Western Canada. Goode et al. (2000) derived a ratio of $14 \pm 1 \mathrm{ppt} \mathrm{ppb}^{-1}$ for forest fire 25 plumes in Alaska.

\section{ACPD}

12, 5705-5738, 2012

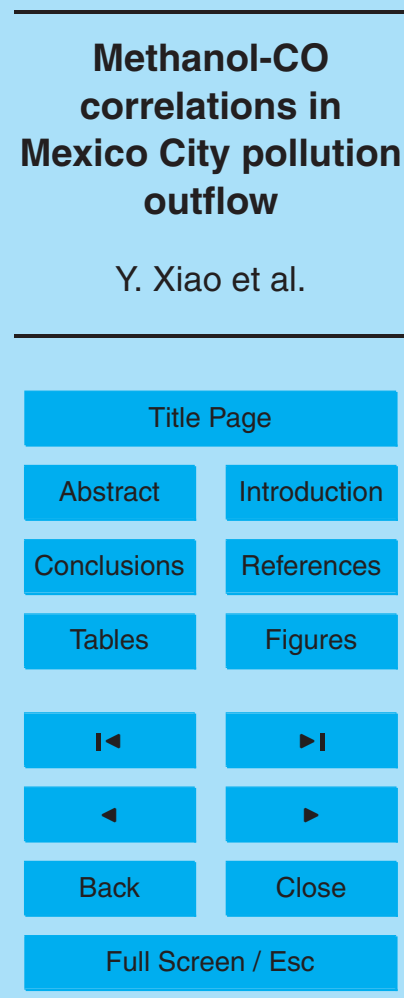

Printer-friendly Version

Interactive Discussion 


\section{Conclusions}

The correlation between $\mathrm{CH}_{3} \mathrm{OH}$ and carbon monoxide $(\mathrm{CO})$ is of interest for characterizing sources of $\mathrm{CH}_{3} \mathrm{OH}$ and other species. Coincident measurements of $\mathrm{CH}_{3} \mathrm{OH}$ and $\mathrm{CO}$ in the lower to middle troposphere from TES and aircraft observations dur-

5 ing MILAGRO allowed us to assess the utility of satellite-based observations of the $\mathrm{CH}_{3} \mathrm{OH}-\mathrm{CO}$ correlation.

TES retrievals of $\mathrm{CH}_{3} \mathrm{OH}$ and $\mathrm{CO}$ show relatively high sensitivity in the $600-800 \mathrm{hPa}$ range, where Mexico City pollution outflow peaks. In-situ aircraft observations of $\mathrm{CH}_{3} \mathrm{OH}$ and $\mathrm{CO}$ downwind of Mexico City center during MILAGRO in March 2006 were 10 used to evaluate the extent to which variability in the $\Delta \mathrm{CH}_{3} \mathrm{OH} / \Delta \mathrm{CO}$ enhancement ratio is captured by TES special observations. During MILAGRO there are sharply peaked outflow profiles (from shallow plumes) that are particularly challenging for TES (or any nadir satellite measurements) to capture due to its vertical resolution $(\sim 5 \mathrm{~km})$. The analysis suggests that the TES operational CO retrieval algorithm (Version 5) maybe 15 improved in regions of elevated topography (e.g. Mexico City) by updating algorithm $\mathrm{CO}$ constraints to better handle elevation changes.

$\triangle \mathrm{CH}_{3} \mathrm{OH} / \triangle \mathrm{CO}$ ratios derived from the TES observations reflect bulk enhancements (smoothed according to the TES sensitivity) of $\mathrm{CH}_{3} \mathrm{OH}$ and $\mathrm{CO}$ in the Mexico City outflow. $\Delta \mathrm{CH}_{3} \mathrm{OH} / \Delta \mathrm{CO}$ ratios derived from the TES observations (18-24 ppt ppb ${ }^{-1}$ )

20 are closer to those observed from DC-8 aircraft during MILAGRO (26-39 ppt ppb ${ }^{-1}$ ), than those from C-130 observations (41-55 ppt ppb $\left.{ }^{-1}\right)$. In a test case of simulated TES $\mathrm{CH}_{3} \mathrm{OH}$ and $\mathrm{CO}$ retrievals with relatively high sensitivity, TES is able to reproduce the $\Delta \mathrm{CH}_{3} \mathrm{OH} / \Delta \mathrm{CO}$ correlation in spite of the coarse vertical resolution of the retrievals. A discrepancy in observed $\Delta \mathrm{CH}_{3} \mathrm{OH} / \Delta \mathrm{CO}$ ratios between the TES and aircraft data could be due to a number of possible systematic errors, including aircraft instrument calibration, TES radiance calibration, TES forward model errors and influence of the a priori constraints on the TES retrievals. The apparent offset between the different aircraft measurements precludes a direct validation of the TES-derived $\mathrm{CH}_{3} \mathrm{OH}: \mathrm{CO}$

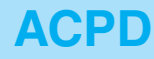

$12,5705-5738,2012$

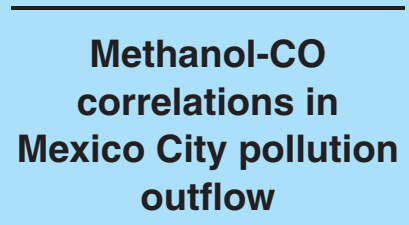

Y. Xiao et al.

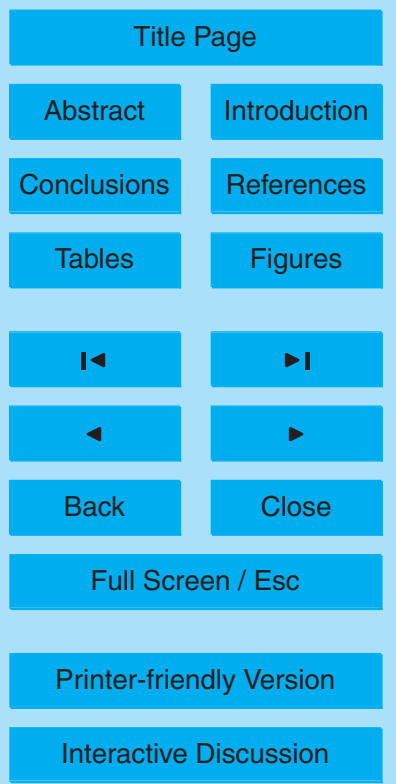


ratios for this analysis. However, the $\mathrm{CH}_{3} \mathrm{OH} / \mathrm{CO}$ enhancement ratios derived from the TES and aircraft data during MILAGRO are both high relative to previous studies over US cities. This may be partly explained by photochemical production of $\mathrm{CH}_{3} \mathrm{OH}$ in fresh plumes as well as to the different types of fuel burned in the MCMA.

5 TES derived $\Delta \mathrm{CH}_{3} \mathrm{OH} / \Delta \mathrm{CO}$ ratios show a significant difference between Mexico City and the Amazon Basin, with substantially higher ratios over the Amazon. Both regions feature strong $\mathrm{CH}_{3} \mathrm{OH}$ emissions: from anthropogenic sources in the first case and from biogenic sources in the second. This analysis shows that TES can clearly distinguish differences in the $\Delta \mathrm{CH}_{3} \mathrm{OH} / \Delta \mathrm{CO}$ ratio due to two different source categories 10 of $\mathrm{CH}_{3} \mathrm{OH}$, which indicates the potential of utilizing TES derived ratios globally as a diagnostic for emission sources in other regions and time periods.

Acknowledgements. This work was supported by NASA through the Atmospheric Chemistry Modeling and Analysis Program (Grant \#NNX10AG65G). Research was partially supported by the Jet Propulsion Laboratory, California Institute of Technology under contract to the National

15 Aeronautics and Space Administration (NASA). We also thank John Worden at NASA/JPL for helpful discussions. We acknowledge Don Blake at University of California, Irvine and Paul Wennberg at California Institute of Technology for sharing their measurements.

\section{References}

Apel, E. C., Emmons, L. K., Karl, T., Flocke, F., Hills, A. J., Madronich, S., Lee-Taylor, J., Fried, A., Weibring, P., Walega, J., Richter, D., Tie, X., Mauldin, L., Campos, T., Weinheimer, A., Knapp, D., Sive, B., Kleinman, L., Springston, S., Zaveri, R., Ortega, J., Voss, P., Blake, D., Baker, A., Warneke, C., Welsh-Bon, D., de Gouw, J., Zheng, J., Zhang, R., Rudolph, J., Junkermann, W., and Riemer, D. D.: Chemical evolution of volatile organic compounds in the outflow of the Mexico City Metropolitan area, Atmos. Chem. Phys., 10, 2353-2375, doi:10.5194/acp-10-2353-2010, 2010.

Alvarado, M. J., Cady-Pereira, K. E., Xiao, Y., Millet, D. B., and Payne, V. H.: Emission Ratios for Ammonia and Formic Acid and Observations of Peroxy Acetyl Nitrate (PAN) and Ethylene

\section{ACPD}

$12,5705-5738,2012$

\section{Methanol-CO \\ correlations in \\ Mexico City pollution \\ outflow}

Y. Xiao et al.

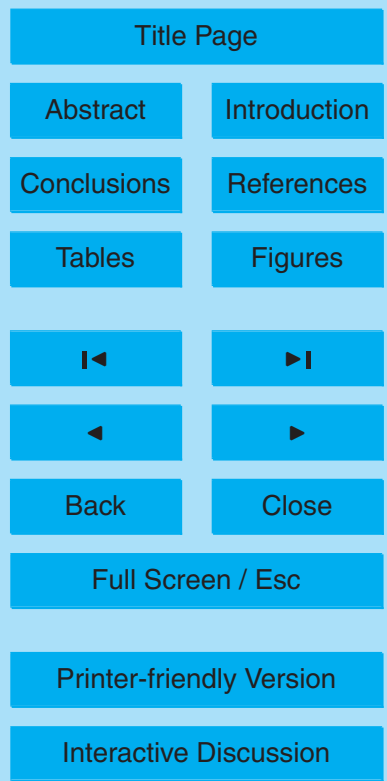


in Biomass Burning Smoke as Seen by the Tropospheric Emission Spectrometer (TES), Atmosphere, 2, 633-654, 2011.

Beer, R., Glavich, T. A., and Rider, D. M.: Tropospheric emission spectrometer for the Earth Observing System's Aura Satellite, Appl. Opt., 40, 2356-2367, 2001.

5 Beer, R., Shephard, M. W., Kulawik, S. S., Clough, S. A., Eldering, A., Bowman, K. W., Sander, S. P., Fisher, B. M., Payne, V. H., Luo, M., Osterman, G. B., and Worden, J. R.: First satellite observations of lower tropospheric ammonia and methanol, Geophys. Res. Lett., 35, L09801, doi:10.1029/2008GL033642, 2008.

Blake, D. R. and Rowland, F. S.: Urban Leakage of Liquefied Petroleum Gas and Its Impact on Mexico-City Air-Quality, Science, 269, 953-956, 1995.

Blando, J. D. and Turpin, B. J.: "Secondary organic aerosol formation in cloud and fog droplets: a literature evaluation of plausibility", Atmos. Environ., 34, 1623-1632, 2000.

Bon, D. M., Ulbrich, I. M., de Gouw, J. A., Warneke, C., Kuster, W. C., Alexander, M. L., Baker, A., Beyersdorf, A. J., Blake, D., Fall, R., Jimenez, J. L., Herndon, S. C., Huey, L. G., Knighton, W. B., Ortega, J., Springston, S., and Vargas, O.: Measurements of volatile organic compounds at a suburban ground site (T1) in Mexico City during the MILAGRO 2006 campaign: measurement comparison, emission ratios, and source attribution, Atmos. Chem. Phys., 11, 2399-2421, doi:10.5194/acp-11-2399-2011, 2011.

Cady-Pereira, K. E., Shephard, M. W., Millet, D. B., Xiao, Y., Luo, M., Wells, K. C., Payne V. H., and Worden, J.: Methanol from Space: Retrieval Strategy and Seasonal and Spatial Variability from TES Global Observations, in preparation, 2012.

Coheur, P.-F., Herbin, H., Clerbaux, C., Hurtmans, D., Wespes, C., Carleer, M., Turquety, S., Rinsland, C. P., Remedios, J., Hauglustaine, D., Boone, C. D., and Bernath, P. F.: ACEFTS observation of a young biomass burning plume: first reported measurements of $\mathrm{C}_{2} \mathrm{H}_{4}$, $\mathrm{C}_{3} \mathrm{H}_{6} \mathrm{O}, \mathrm{H}_{2} \mathrm{CO}$ and PAN by infrared occultation from space, Atmos. Chem. Phys., 7, 54375446, doi:10.5194/acp-7-5437-2007, 2007.

Connor, T. C., Shephard, M. W., Payne, V. H., Cady-Pereira, K. E., Kulawik, S. S., Luo, M., Osterman, G., and Lampel, M.: Long-term stability of TES satellite radiance measurements, Atmos. Meas. Tech., 4, 1481-1490, doi:10.5194/amt-4-1481-2011, 2011.

30 Crounse, J. D., DeCarlo, P. F., Blake, D. R., Emmons, L. K., Campos, T. L., Apel, E. C., Clarke, A. D., Weinheimer, A. J., McCabe, D. C., Yokelson, R. J., Jimenez, J. L., and Wennberg, P. O.: Biomass burning and urban air pollution over the Central Mexican Plateau, Atmos. Chem. Phys., 9, 4929-4944, doi:10.5194/acp-9-4929-2009, 2009.

\section{Methanol-CO correlations in Mexico City pollution outflow}

Y. Xiao et al.

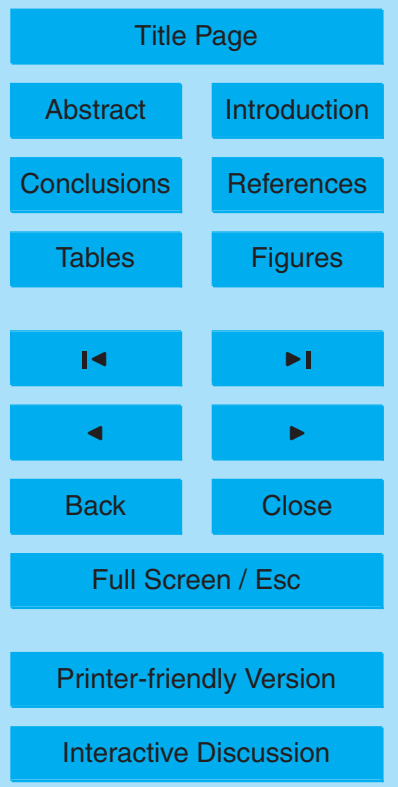


de Gouw, J. A., Middlebrook, A. M., Warneke, C., Goldan, P. D., Kuster, W. C., Roberts, J. M., Fehsenfeld, F. C., Worsnop, D. R., Canagaratna, M. R., Pszenny, A. A. P., Keene, W. C., Marchewka, M., Bertman, S. B., and Bates, T. S.: Budget of organic carbon in a polluted atmosphere: Results from the New England Air Quality Study in 2002, J. Geophys. Res., 110, D16305, doi:10.1029/2004JD005623, 2005.

de Gouw, J. A., Warneke, C., Stohl, A., Wollny, A. G., Brock, C. A., Cooper, O. R., Holloway, J. S., Trainer, M., Fehsenfeld, F. C., Atlas, E. L., Donnelly, S. G., Stroud, V., and Lueb, A.: Volatile organic compounds composition of merged and aged forest fire plumes from Alaska and western Canada, J. Geophys. Res., 111, D10303, doi:10.1029/2005JD006175, 2006.

10 de Gouw, J. A., Welsh-Bon, D., Warneke, C., Kuster, W. C., Alexander, L., Baker, A. K., Beyersdorf, A. J., Blake, D. R., Canagaratna, M., Celada, A. T., Huey, L. G., Junkermann, W., Onasch, T. B., Salcido, A., Sjostedt, S. J., Sullivan, A. P., Tanner, D. J., Vargas, O., Weber, R. J., Worsnop, D. R., Yu, X. Y., and Zaveri, R.: Emission and chemistry of organic carbon in the gas and aerosol phase at a sub-urban site near Mexico City in March 2006 during the 15 MILAGRO study, Atmos. Chem. Phys., 9, 3425-3442, doi:10.5194/acp-9-3425-2009, 2009.

de Foy, B., Varela, J. R., Molina, L. T., and Molina, M. J.: Rapid ventilation of the Mexico City basin and regional fate of the urban plume, Atmos. Chem. Phys., 6, 2321-2335, doi:10.5194/acp-6-2321-2006, 2006.

Dufour, G., Boone, C. D., Rinsland, C. P., and Bernath, P. F.: First space-borne measurements of methanol inside aged southern tropical to mid-latitude biomass burning plumes using the ACE-FTS instrument, Atmos. Chem. Phys., 6, 3463-3470, doi:10.5194/acp-6-3463-2006, 2006.

Duncan, B. N., Logan, J. A., Bey, I., Megretskaia, I. A., Yantosca, R. M., Novelli, P. C., Jones, N. B., and Rinsland, C. P.: Global budget of CO, 1988-1997: Source estimates and validation with a global model, J. Geophys. Res., 112, D22301, doi:10.1029/2007jd008459, 2007.

Fischer, E. V., Jacob, D. J., Millet, D. B., Yantosca, R. M., and Mao, J.: The role of the ocean in the global atmospheric budget of acetone, Geophys. Res. Lett., 39, L01807, doi:10.1029/2011GL050086, 2012.

Galbally, I. E. and Kirstine, W.: The production of methanol by flowering plants and the global cycle of methanol, J. Atmos. Chem., 43, 195-229, 2002.

Goldan, P. D., Trainer, M., Kuster, W. C., Parrish, D. D., Carpenter, J., Roberts, J. M., Yee, J. E., and Fehsenfeld, F. C.: Measurements of hydrocarbons, oxygenated hydrocarbons, carbonmonoxide, and nitrogen-oxides in an urban basin in Colorado - Implications for emissions

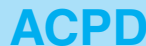

$12,5705-5738,2012$

\section{Methanol-CO correlations in \\ Mexico City pollution outflow}

Y. Xiao et al.

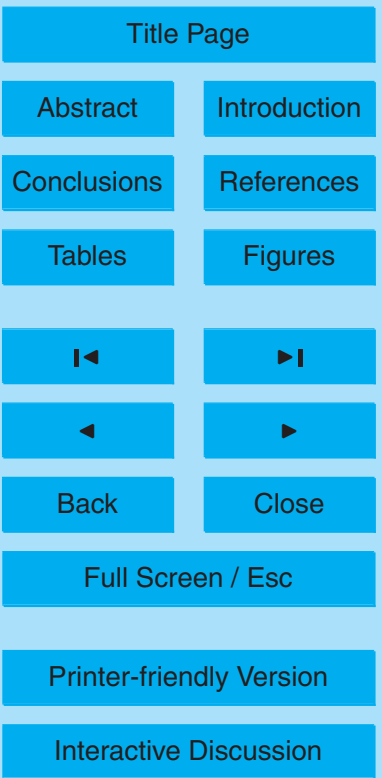


inventories, J. Geophys. Res., 100, 22771-22783, 1995.

Goode, J. G., Yokelson, R. J., Ward, D. E., Susott, R. A., Babbitt, R. E., Davies, M. A., and Hao, W. M.: Measurements of excess $\mathrm{O}_{3}, \mathrm{CO}_{2}, \mathrm{CO}, \mathrm{CH}_{4}, \mathrm{C}_{2} \mathrm{H}_{4}, \mathrm{C}_{2} \mathrm{H}_{2}, \mathrm{HCN}, \mathrm{NO} \mathrm{NH}, \mathrm{HCOOH}$, $\mathrm{CH}_{3} \mathrm{COOH}, \mathrm{HCHO}$ and $\mathrm{CH}_{3} \mathrm{OH}$ in 1997 Alaskan biomass burning plumes by airborne Fourier 5 transform infrared spectroscopy (AFTIR), J. Geophys. Res., 105, 22147-22166, 2000.

Harley, P., Greenberg, J., Niinemets, ., and Guenther, A.: Environmental controls over methanol emission from leaves, Biogeosciences, 4, 1083-1099, doi:10.5194/bg-4-1083-2007, 2007.

Harley, R. A., Hannigan, M. P., and Cass, G. R.: Respeciation of organic gas emissions and the detection of excess unburned gasoline in the atmosphere, Environ. Sci. Technol., 26, $10 \quad$ 2395-2408, doi:10.1021/es00036a010, 1992.

Heikes, B. G., Chang, W., Pilson, M. E. Q., Swift, E., Singh, H. B., Guenther, A., Jacob, D. J., and Brand, L.: Atmospheric methanol budget and ocean implication, Global Biogeochem. Cy., 16, 1133, doi:10.1029/2002GB001895, 2002.

Hirsch, R. M. and Gilroy, E. J.: Methods of fitting a straight line to data: Examples in water resources, Water Resour. Bull., 20, 705-711, 1984.

Holloway, J. S., Jakoubek, R. O., Parrish, D. D., Gerbig, C., Volz-Thomas, A., Schmitgen, S., Fried, A., Wert, B., Henry, B., and Drummond, J. R.: Airborne intercomparison of vacuum ultraviolet fluorescence and tunable diode laser absorption measurements of tropospheric carbon monoxide, J. Geophys. Res., 105, 24251-24261, 2000.

20 Holzinger, R., Williams, J., Salisbury, G., Klüpfel, T., de Reus, M., Traub, M., Crutzen, P. J., and Lelieveld, J.: Oxygenated compounds in aged biomass burning plumes over the Eastern Mediterranean: evidence for strong secondary production of methanol and acetone, Atmos. Chem. Phys., 5, 39-46, doi:10.5194/acp-5-39-2005, 2005.

Hu, L., Millet, D. B., Mohr, M. J., Wells, K. C., Griffis, T. J., and Helmig, D.: Sources and seasonality of atmospheric methanol based on tall tower measurements in the US Upper Midwest, Atmos. Chem. Phys., 11, 11145-11156, doi:10.5194/acp-11-11145-2011, 2011.

Jacob, D. J., Field, B. D., Li, Q. B., Blake, D. R., de Gouw, J., Warneke, C., Hansel, A., Wisthaler, A., Singh, H. B., and Guenther, A.: Global budget of methanol: Constraints from atmospheric observations, J. Geophys. Res., 110, D08303, doi:10.1029/2004JD005172, 2005

30 Karl, T., Guenther, A., Spirig, C., Hansel, A., and Fall, R.: Seasonal variation of biogenic VOC emissions above a mixed hardwood forest in Northern Michigan, Geophys. Res. Lett., 30, 2186, doi:10.1029/2003GL018432, 2003.

Karl, T., Guenther, A., Yokelson, R. J., Greenberg, J., Potosnak, M., Blake, D. R., and Artaxo,

\section{Methanol-CO \\ correlations in \\ Mexico City pollution outflow}

Y. Xiao et al.

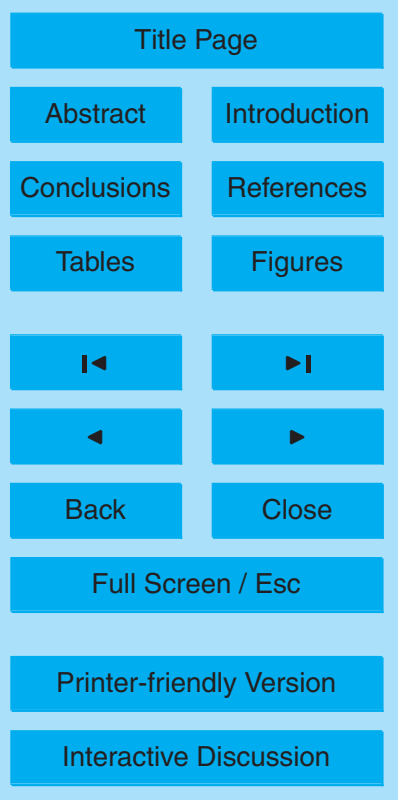


P.: The tropical forest and fire emissions experiment: Emission, chemistry, and transport of biogenic volatile organic compounds in the lower atmosphere over Amazonia, J. Geophys. Res.-Atmos., 112, D18302, doi:10.1029/2007jd008539, 2007.

Karl, T., Apel, E., Hodzic, A., Riemer, D. D., Blake, D. R., and Wiedinmyer, C.: Emissions 5 of volatile organic compounds inferred from airborne flux measurements over a megacity, Atmos. Chem. Phys., 9, 271-285, doi:10.5194/acp-9-271-2009, 2009

Karl, T., Harley, P., Emmons, L., Thornton, B., Guenther, A., Basu, C., Turnipseed, A., and Jardine, K.: Efficient Atmospheric Cleansing of Oxidized Organic Trace Gases by Vegetation, Science, 330, 816-819, 2010.

10 Kleb, M. M., Chen, G., Crawford, J. H., Flocke, F. M., and Brown, C. C.: An overview of measurement comparisons from the INTEX-B/MILAGRO airborne field campaign, Atmos. Meas. Tech., 4, 9-27, doi:10.5194/amt-4-9-2011, 2011.

Lopez, J. P., Luo, M., Christensen, L. E., Loewenstein, M., Jost, H., Webster, C. R., and Osterman, G.: TES carbon monoxide validation during two AVE campaigns using the Argus and ALIAS instruments on NASA's WB-57F, J. Geophys. Res., 113, D16S47, doi:10.1029/2007JD008811, 2008.

Luo, M., Rinsland, C. P., Rodgers, C. D., Logan, J. A., Worden, H., Kulawik, S., Eldering, A., Goldman, A., Shephard, M. W., Gunson, M., and Lampel, M.: Comparison of carbon monoxide measurements by TES and MOPITT: Influence of a priori data and instrument characteristics on nadir atmospheric species retrievals, J. Geophys. Res., 112, D09303, doi:10.1029/2006JD007663, 2007a.

Luo, M., Rinsland, C., Fisher, B., Sachse, G., Diskin, G., Logan, J., Worden, H., Kulawik, S., Osterman, G., Eldering, A., Herman, R., and Shephard, M.: TES carbon monoxide validation with DACOM aircraft measurements during INTEX-B 2006, J. Geophys. Res., 112, D24S48, doi:10.1029/2007JD008803, 2007b.

Madronich, S. and Calvert, J. G.: Permutation reactions of organic peroxy radicals in the troposphere, J. Geophys. Res., 95, 5697-5715, 1990.

Millet, D. B., Jacob, D. J., Turquety, S., Hudman, R. C., Wu, S., Fried, A., Walega, J., Heikes, B. G., Blake, D. R., Singh, H. B., Anderson, B. E., and Clarke, A. D.: Formaldehyde distribution over North America: Implications for satellite retrievals of formaldehyde columns and isoprene emission, J. Geosphys. Res., 111, D24S02, doi:10.1029/2005jd006853, 2006.

Millet, D. B., Jacob, D. J., Custer, T. G., de Gouw, J. A., Goldstein, A. H., Karl, T., Singh, H. B., Sive, B. C., Talbot, R. W., Warneke, C., and Williams, J.: New constraints on terres-

\section{ACPD}

$12,5705-5738,2012$

\section{Methanol-CO \\ correlations in \\ Mexico City pollution \\ outflow}

Y. Xiao et al.

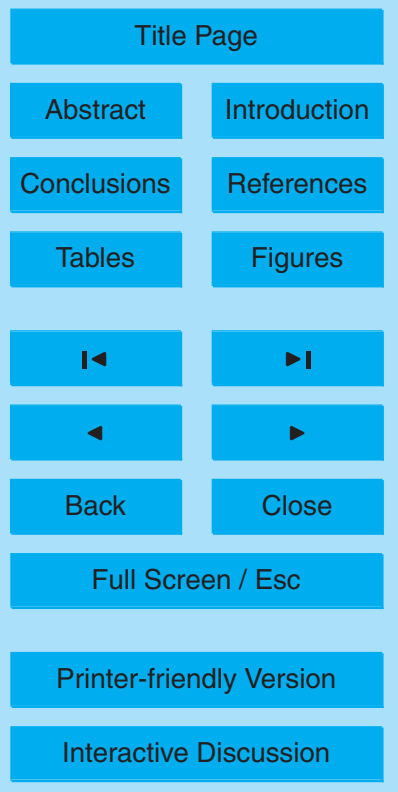


trial and oceanic sources of atmospheric methanol, Atmos. Chem. Phys., 8, 6887-6905, doi:10.5194/acp-8-6887-2008, 2008.

Molina, L. T., Madronich, S., Gaffney, J. S., Apel, E., de Foy, B., Fast, J., Ferrare, R., Herndon, S., Jimenez, J. L., Lamb, B., Osornio-Vargas, A. R., Russell, P., Schauer, J. J., Stevens, P.

S., Volkamer, R., and Zavala, M.: An overview of the MILAGRO 2006 Campaign: Mexico City emissions and their transport and transformation, Atmos. Chem. Phys., 10, 8697-8760, doi:10.5194/acp-10-8697-2010, 2010.

Payne, V. H., Clough, S. A., Shephard, M. W., Nassar, R., and Logan, J. A.: Informationcentered representation of retrievals with limited degrees of freedom for signal: Application to methane from the Tropospheric Emission Spectrometer, J. Geophys. Res., 114, D10307, doi:10.1029/2008jd010155, 2009.

Paton-Walsh, C., Wilson, S. R., Jones, N. B., and Griffith, D. W. T.: Measurement of methanol emissions from Australian wildfires by ground-based solar Fourier transform spectroscopy, Geophys. Res. Lett., 35, L08810, doi:10.1029/2007GL032951, 2008.

15 Razavi, A., Karagulian, F., Clarisse, L., Hurtmans, D., Coheur, P. F., Clerbaux, C., Müller, J. F., and Stavrakou, T.: Global distributions of methanol and formic acid retrieved for the first time from the IASI/MetOp thermal infrared sounder, Atmos. Chem. Phys., 11, 857-872, doi:10.5194/acp-11-857-2011, 2011.

Rinsland, C. P., Mahieu, E., Chiou, L., and Herbin, H.: First ground-based infrared solar absorption measurements of free tropospheric methanol $\left(\mathrm{CH}_{3} \mathrm{OH}\right)$ : Multidecade infrared time series from Kitt Peak $\left(31.9^{\circ} \mathrm{N} 111.6^{\circ} \mathrm{W}\right)$ : Trend, seasonal cycle, and comparison with previous measurements, J. Geophys. Res., 114, D04309, doi:10.1029/2008JD011003, 2009.

Sachse, G. W., Hill, G. F., Wade, L. O., and Perry, M. G.: Fastresponse, high-precision carbon monoxide sensor using a tunable diode-laser absorption technique, J. Geophys. Res., 92, 2071-2081, 1987.

Shephard, M. W., Worden, H. M., Cady-Pereira, K. E., Lampel, M., Luo, M., Bowman, K. W., Sarkissian, E., Beer, R., Rider, D. M., Tobin, D. C., Revercomb, H. E., Fisher, B. M., Tremblay, D., Clough, S. A., Osterman, G. B., and Gunson, M.: Tropospheric Emission Spectrometer Spectral Radiance Comparisons, J. Geophys. Res., 113, D15S05, doi:10.1029/2007JD008856, 2008.

Shephard, M. W., Cady-Pereira, K. E., Luo, M., Henze, D. K., Pinder, R. W., Walker, J. T., Rinsland, C. P., Bash, J. O., Zhu, L., Payne, V. H., and Clarisse, L.: TES ammonia retrieval strategy and global observations of the spatial and seasonal variability of ammonia, Atmos.
12, 5705-5738, 2012

\section{Methanol-CO \\ correlations in \\ Mexico City pollution \\ outflow}

Y. Xiao et al.

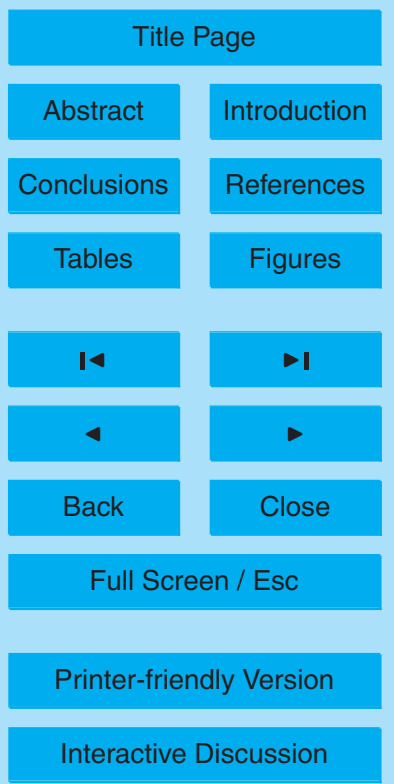

Interactive Discussion 
Chem. Phys., 11, 10743-10763, doi:10.5194/acp-11-10743-2011, 2011.

Shim, C., Li, Q., Luo, M., Kulawik, S., Worden, H., Worden, J., Eldering, A., Diskin, G., Sachse, G., Weinheimer, A., Knapp, D., Montzca, D., and Campos, T.: Satellite observations of Mexico City pollution outflow from the Tropospheric Emissions Spectrometer (TES), Atmos. Environ., 43, 1540-1547, doi:10.1016/j.atmosenv.2008.11.026, 2009.

Simpson, I. J., Akagi, S. K., Barletta, B., Blake, N. J., Choi, Y., Diskin, G. S., Fried, A., Fuelberg, H. E., Meinardi, S., Rowland, F. S., Vay, S. A., Weinheimer, A. J., Wennberg, P. O., Wiebring, P., Wisthaler, A., Yang, M., Yokelson, R. J., and Blake, D. R.: Boreal forest fire emissions in fresh Canadian smoke plumes: $\mathrm{C} 1-\mathrm{C} 10$ volatile organic compounds (VOCs), $\mathrm{CO}_{2}$, $\mathrm{CO}, \mathrm{NO}_{2}, \mathrm{NO}, \mathrm{HCN}$ and $\mathrm{CH}_{3} \mathrm{CN}$, Atmos. Chem. Phys., 11, 6445-6463, doi:10.5194/acp-116445-2011, 2011.

Singh, H. B., Kanakidou, M., Crutzen P. J., and Jacob, D. J.: High-Concentrations and Photochemical Fate of Oxygenated Hydrocarbons in the Global Troposphere, Nature, 378, 50-54, 6552, doi:10.1038/378050a0, 1995.

Singh, H. B., Tabazadeh, A., Fukui, Y., Bey, I., Yantosca, R., Jacob, D., Arnold, F., Wohlfrom K., Atlas, E., Flocke, F., Blake, D., Blake, N., Heikes, B., Snow, J., Talbot, R., Gregory, G., Sachse, G., Vay, S., and Kondo, Y.: Distribution and fate of selected oxygenated organic species in the troposphere and lower stratosphere over the Atlantic, J. Geophys. Res., 105, 3795-3805, 2000.

20 Singh, H. B., Salas, L. J., Chatfield, R. B., Czech, E., Fried, A., Walega, J., Evans, M. J., Field, B. D., Jacob, D. J., Blake, D., Heikes, B., Talbot, R., Sachse, G., Crawford, J. H., Avery, M. A., Sandholm, S., and Fuelberg, H.: Analysis of the atmospheric distribution, sources, and sinks of oxygenated volatile organic chemicals based on measurements over the Pacific during TRACE-P, J. Geophys. Res., 109, D15S07, doi:10.1029/2003JD003883, 2004.

Singh, H. B., Brune, W. H., Crawford, J. H., Flocke, F., and Jacob, D. J.: Chemistry and transport of pollution over the Gulf of Mexico and the Pacific: spring 2006 INTEX-B campaign overview and first results, Atmos. Chem. Phys., 9, 2301-2318, doi:10.5194/acp-9-2301-2009, 2009.

Singh, H. B., Anderson, B. E., Brune, W. H., Cai, C., Cohen, R. C., Crawford, J. H., Cubison, M. J., Czech, E. P., Emmons, L., Fuelberg, H. E., Huey, G., Jacob, D. J., Jimenez, J. L., Kaduwela, A., Kondo, Y., Mao, J., Olson, J. R., Sachse, G. W., Vay, S. A., Weinheimer, A., Wennberg, P. O., Wisthaler, A., and the ARCTAS Science Team: Pollution influences on atmospheric composition and chemistry at high northern latitudes: Boreal and California forest fire emissions, Atmos. Environ., 44, 4553-4564, doi:10.1016/j.atmosenv.2010.08.026,

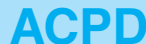

12, 5705-5738, 2012

\section{Methanol-CO \\ correlations in \\ Mexico City pollution \\ outflow}

Y. Xiao et al.

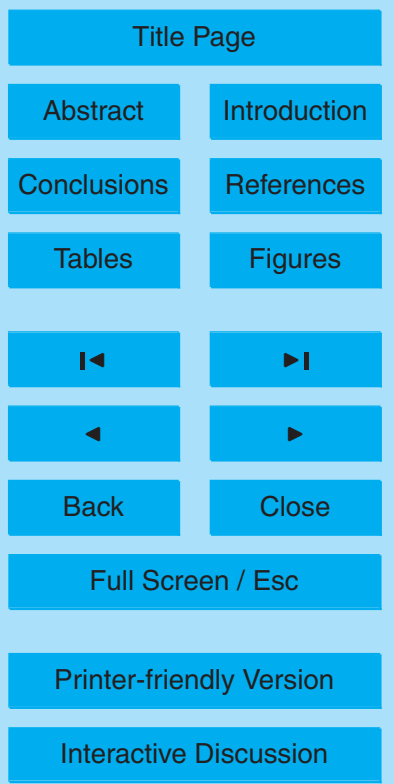


2010.

Stavrakou, T., Guenther, A., Razavi, A., Clarisse, L., Clerbaux, C., Coheur, P.-F., Hurtmans, D., Karagulian, F., De Mazière, M., Vigouroux, C., Amelynck, C., Schoon, N., Laffineur, Q., Heinesch, B., Aubinet, M., Rinsland, C., and Müller, J.-F.: First space-based derivation of the global atmospheric methanol emission fluxes, Atmos. Chem. Phys., 11, 4873-4898, doi:10.5194/acp-11-4873-2011, 2011.

Tie, X., Guenther, A., and Holland, E.: Biogenic methanol and its impacts on tropospheric oxidants, Geophys. Res. Lett., 30, 1881, doi:10.1029/2003GL017167, 2003.

Tyndall, G. S., Cox, R. A., Granier, C., Lesclaux, R., Moortgat, G. K., Pilling, M. J., Ravishankara, A. R., and Wallington, T. J.: Atmospheric chemistry of small organic peroxy radicals, J. Geophys. Res., 106, 12157-12182, 2001.

Warneke, C., Karl, T., Judmaier, H., Hansel, A., Jordan, A., Lindinger, W., and Crutzen, P. J.: Acetone, methanol, and other partially oxidized volatile organic emissions from dead plant matter by abiological processes: Significance for atmospheric HOx chemistry, Global

15 Biogeochem. Cy., 13, 9-17, doi:10.1029/98gb02428, 1999.

Warneke, C., McKeen, S. A., de Gouw, J. A., Goldan, P. D., Kuster, W. C., Holloway, J. S., Williams, E. J., Lerner, B. M., Parrish, D. D., Trainer, M., Fehsenfeld, F. C., Kato, S., Atlas, E. L., Baker, A., and Blake, D. R.: Determination of urban volatile organic compound emission ratios and comparison with an emissions database, J. Geophys. Res., 112, D10S47, doi:10.1029/2006JD007930, 2007.

Wells K., Millet, D., Cady-Pereira, K., Shephard, M., Xiao, Y., Razavi, A., Clerbaux, C., Clarisse, L., Coheur, P. F., E. Apel, de Gouw, J., Warneke, C., Singh, H., Goldstein, A., Hu, L., and Sive, B.: Tropospheric methanol observations from space: Retrieval evaluation and constraints on the seasonality of biogenic emissions, Atmos. Chem. Phys., in press, 2012.

Xiao, Y. P., Jacob, D. J., Wang, J. S., Logan, J. A., Palmer, P. I., Suntharalingam, P., Yantosca, R. M., Sachse, G. W., Blake, D. R., and Streets, D. G.: Constraints on Asian and European sources of methane from $\mathrm{CH}_{4}-\mathrm{C}_{2} \mathrm{H}_{6}-\mathrm{CO}$ correlations in Asian outflow, J. Geophys. Res., 109, D15S16, doi:10.1029/2003JD004475, 2004

Yokelson, R. J., Urbanski, S. P., Atlas, E. L., Toohey, D. W., Alvarado, E. C., Crounse, J. D., 30 Wennberg, P. O., Fisher, M. E., Wold, C. E., Campos, T. L., Adachi, K., Buseck, P. R., and Hao, W. M.: Emissions from forest fires near Mexico City, Atmos. Chem. Phys., 7, 55695584, doi:10.5194/acp-7-5569-2007, 2007.

Yokelson, R. J., Crounse, J. D., DeCarlo, P. F., Karl, T., Urbanski, S., Atlas, E., Campos, T.,

\section{Methanol-CO correlations in \\ Mexico City pollution outflow}

Y. Xiao et al.

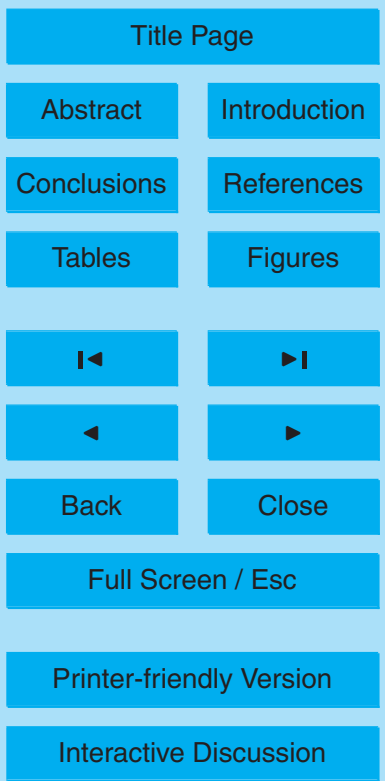


Shinozuka, Y., Kapustin, V., Clarke, A. D., Weinheimer, A., Knapp, D. J., Montzka, D. D., Holloway, J., Weibring, P., Flocke, F., Zheng, W., Toohey, D., Wennberg, P. O., Wiedinmyer, C., Mauldin, L., Fried, A., Richter, D., Walega, J., Jimenez, J. L., Adachi, K., Buseck, P. R., Hall, S. R., and Shetter, R.: Emissions from biomass burning in the Yucatan, Atmos. Chem. Phys., 9, 5785-5812, doi:10.5194/acp-9-5785-2009, 2009.

Yokelson, R. J., Burling, I. R., Urbanski, S. P., Atlas, E. L., Adachi, K., Buseck, P. R., Wiedinmyer, C., Akagi, S. K., Toohey, D. W., and Wold, C. E.: Trace gas and particle emissions from open biomass burning in Mexico, Atmos. Chem. Phys., 11, 6787-6808, doi:10.5194/acp-116787-2011, 2011.

\section{ACPD}

$12,5705-5738,2012$

\section{Methanol-CO correlations in Mexico City pollution outflow}

Y. Xiao et al.

Title Page
Abstract

Conclusions

Tables

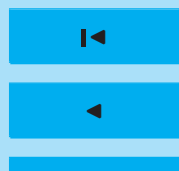

Back
Introduction

References
Full Screen / Esc

Printer-friendly Version

Interactive Discussion 


\section{ACPD}

12, 5705-5738, 2012

Table 1. The $\Delta \mathrm{CH}_{3} \mathrm{OH} / \Delta \mathrm{CO}$ ratio (in pptppb ${ }^{-1}$ ) from the aircraft and TES from this study versus those from the literature.

\begin{tabular}{lll}
\hline$\Delta \mathrm{CH}_{3} \mathrm{OH} / \Delta \mathrm{CO}\left(\mathrm{pptppb}^{-1}\right)$ & Fuel/Location/Season & Source \\
\hline $41-44(\mathrm{C}-130)$ 26-39 (DC-8) & Urban outflow/Mexico City/March & This Study \\
$18-24(\mathrm{TES})$ & Urban outflow/Mexico City/March & This Study \\
$42 \pm 7(\mathrm{TES})$ & Plants emissions/Amazon basin/August-September & This Study \\
$21.0 \pm 14.0$ & Urban plumes/California & Singh et al. (2010) \\
9.0 & Urban plumes/New York City and Boston/summer & Warneke et al. (2007) \\
8.4 & Urban plumes/Los Angeles/spring & Warneke et al. (2007) \\
$4-11$ & Ground samples/Boulder and Pittsburgh/winter & Millet et al. (2005); Goldan et al. (2005) \\
$14-28$ & Fire plumes/Mexico/spring & Yokelson et al. (2009) \\
$19-32$ & Open fires/Mexico/spring & Yokelson et al. (2011) \\
$9.6 \pm 1.9$ & Fresh fire plumes/Canada & Simpson et al. (2011) \\
$15.6 \pm 9.2$ & Fresh fire plumes/Canada & Singh et al. (2011) \\
$10.8 \pm 4.4$ & Aged fire plumes/Alaska and western Canada & De Gouw et al. (2006) \\
$14 \pm 1$ & Forest fire plumes/Alaska & Goode et al. (2000)
\end{tabular}

\section{Methanol-CO correlations in Mexico City pollution outflow}

Y. Xiao et al.

\section{Title Page}

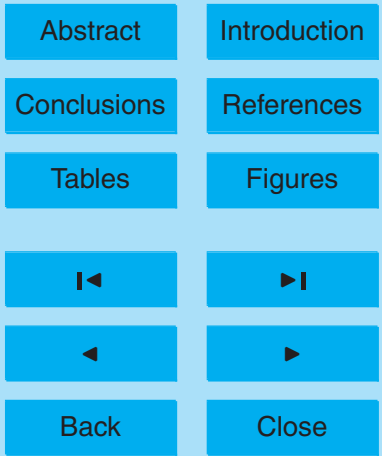

Full Screen / Esc

Printer-friendly Version

Interactive Discussion 


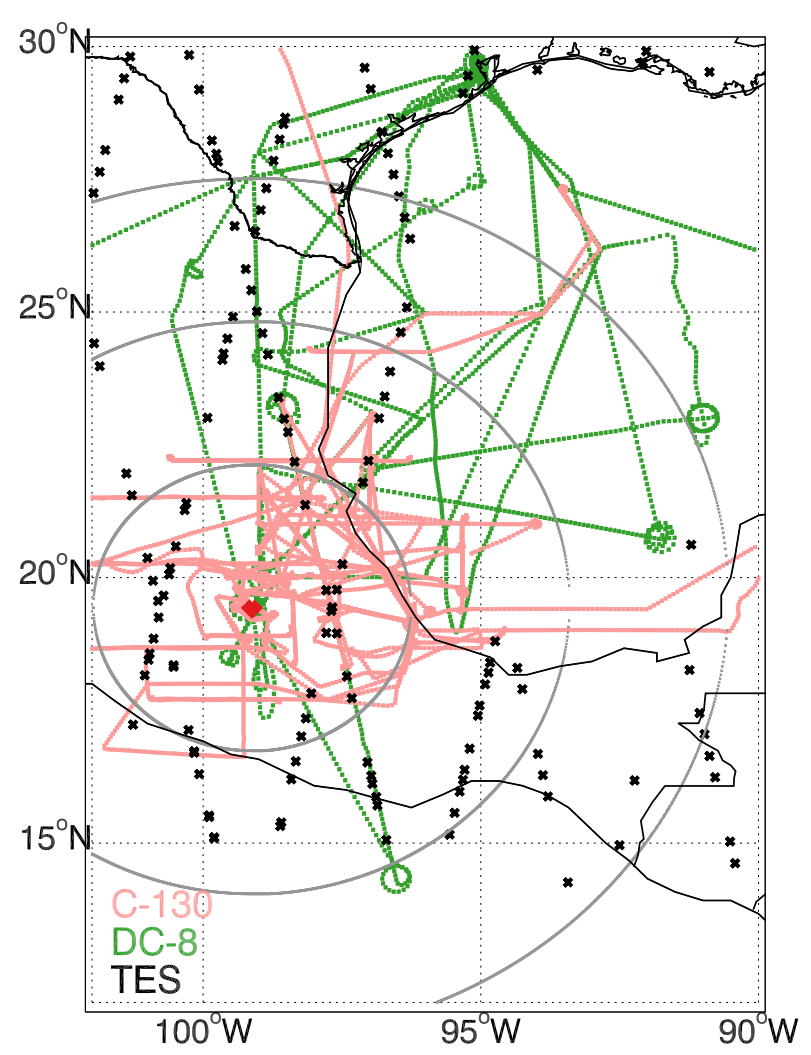

Fig. 1. Aircraft flight tracks (C-130 in pink, $D C-8$ in green) and TES footprints (black crosses) during MILAGRO. Circles show radii of 300,600 and $900 \mathrm{~km}$ from the center of Mexico City (red diamond).

\section{ACPD}

12, 5705-5738, 2012

\section{Methanol-CO correlations in \\ Mexico City pollution outflow}

Y. Xiao et al.

Title Page

Abstract

Introduction

Conclusions

References

Tables

Figures

14

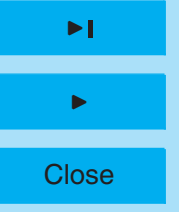

Back

Full Screen / Esc

Printer-friendly Version

Interactive Discussion 

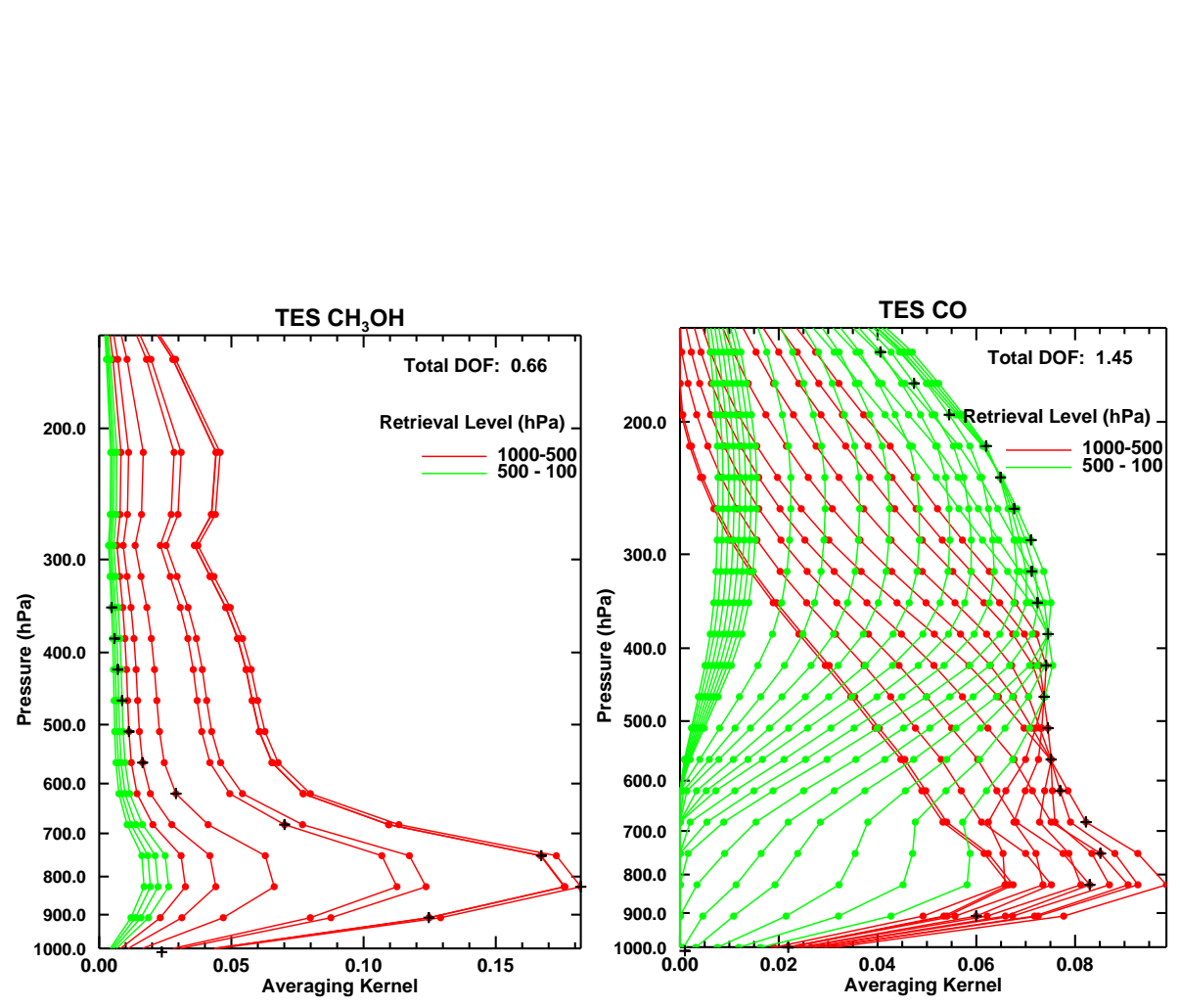

\section{ACPD}

12, 5705-5738, 2012

\section{Methanol-CO correlations in}

Mexico City pollution outflow

Y. Xiao et al.

Title Page

\section{Abstract}

Conclusions
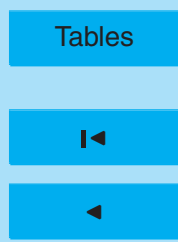

Back

Full Screen / Esc

Printer-friendly Version

Interactive Discussion 

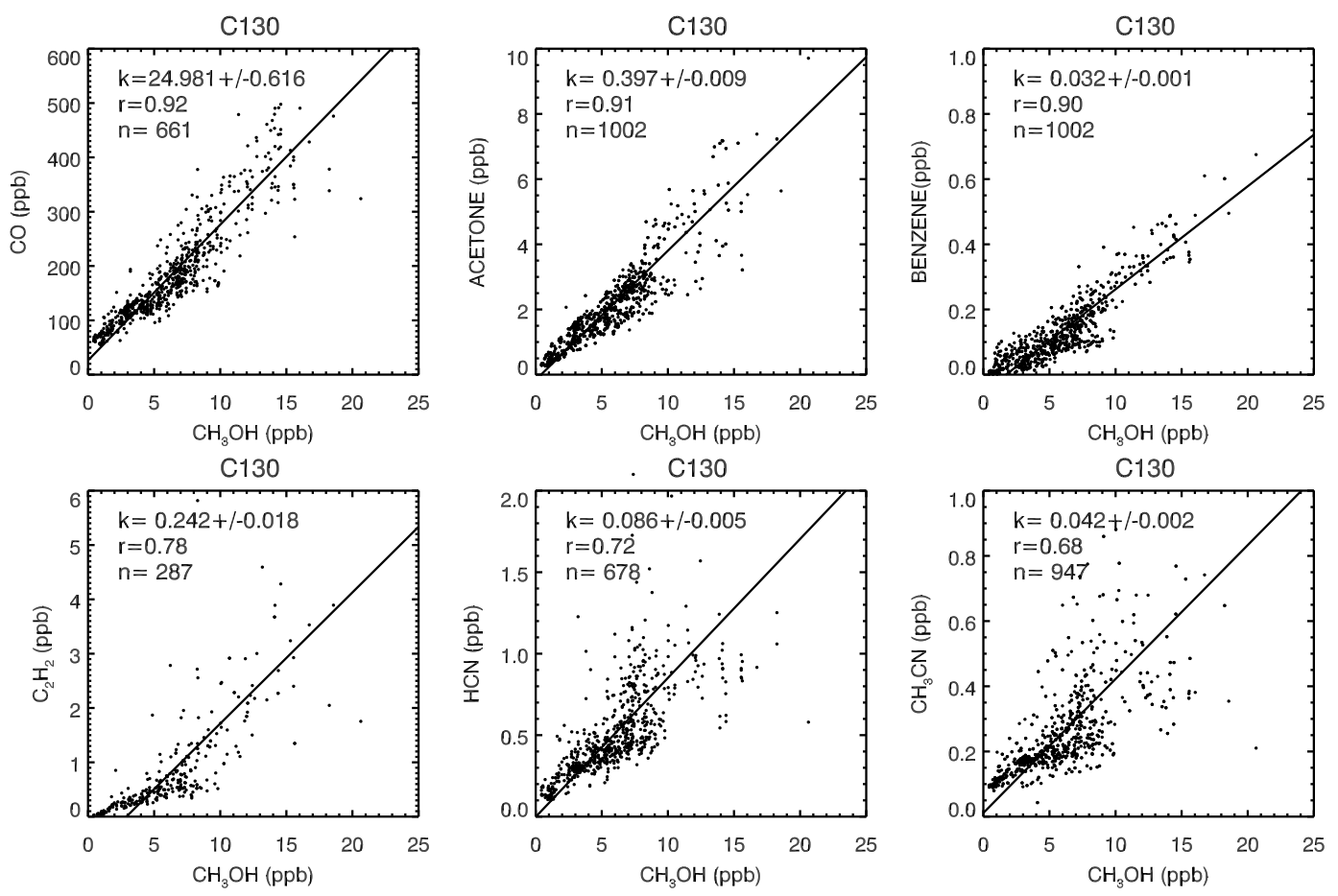

ACPD

$12,5705-5738,2012$

\section{Methanol-CO correlations in \\ Mexico City pollution outflow}

Y. Xiao et al.

Fig. 3. Correlations between $\mathrm{CH}_{3} \mathrm{OH}$ and a suite of gases (CO, acetone, benzene, $\mathrm{C}_{2} \mathrm{H}_{2}, \mathrm{HCN}$ and $\mathrm{CH}_{3} \mathrm{CN}$ ) from a subset of $\mathrm{C}-130$ measurements near the source region (within $300 \mathrm{~km}$ of the Mexico City center and below $600 \mathrm{mb}$ ) during MILAGRO. Regression slopes $(k)$, correlation coefficients $(r)$ and the sample count $(n)$ are shown. 

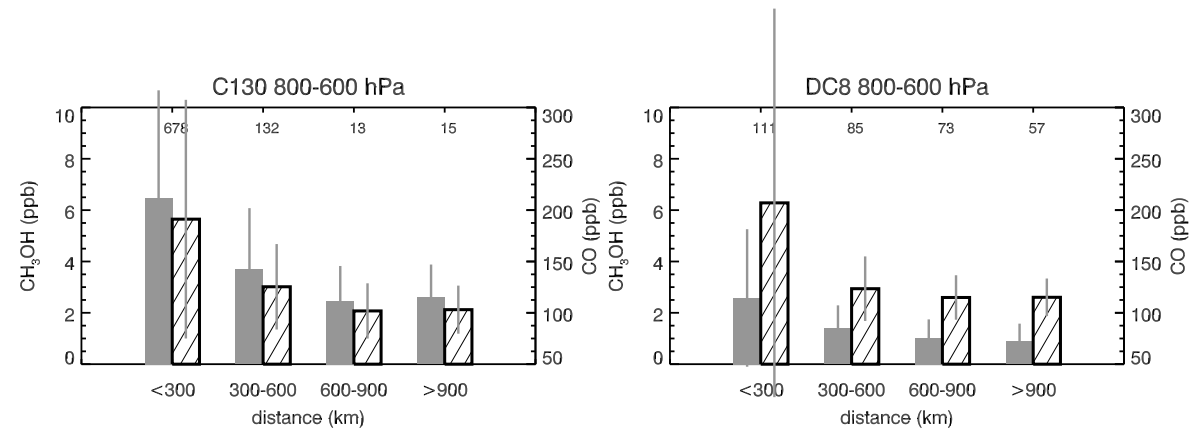

TES RVMR

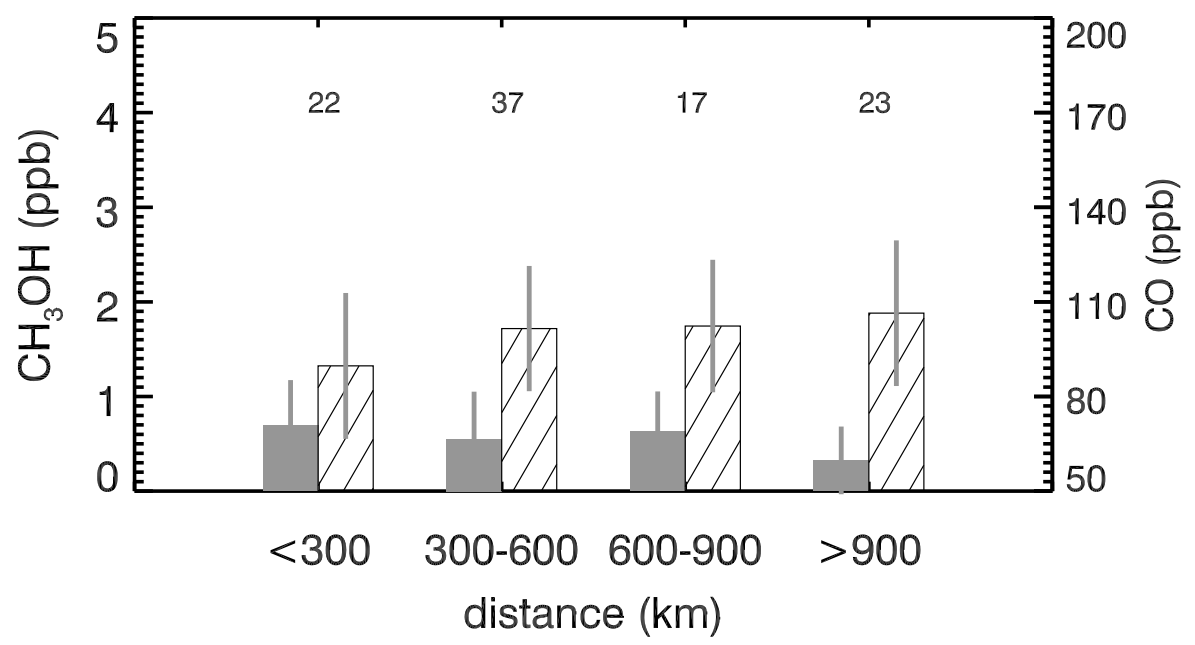

Fig. 4. Spatial variation of $\mathrm{CH}_{3} \mathrm{OH}$ (grey bars, left axis) and $\mathrm{CO}$ (hatched bars, right axis) concentrations with distance from Mexico City Center during MILAGRO, based on the C-130 aircraft (a), DC-8 aircraft (b), and TES space-based (c) observations.
$12,5705-5738,2012$

\section{Methanol-CO correlations in \\ Mexico City pollution outflow}

Y. Xiao et al.

Title Page

Abstract

Introduction

Conclusions

References

Tables

Figures

14

$\rightarrow$

4

Back

Close

Full Screen / Esc

Printer-friendly Version

Interactive Discussion 
(a)

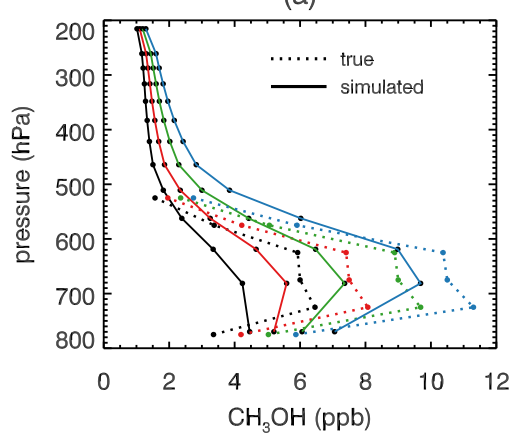

(c) Aircraft $\mathrm{CH}_{3} \mathrm{OH}-\mathrm{CO}$

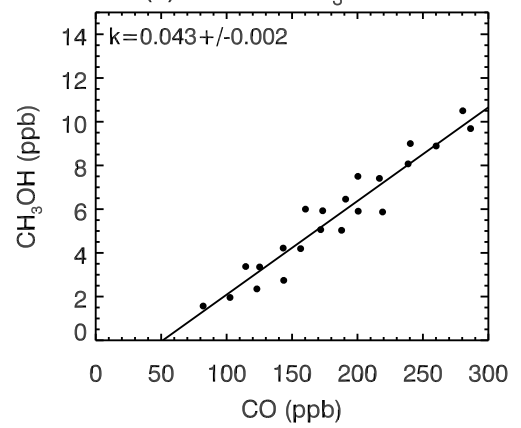

(b)

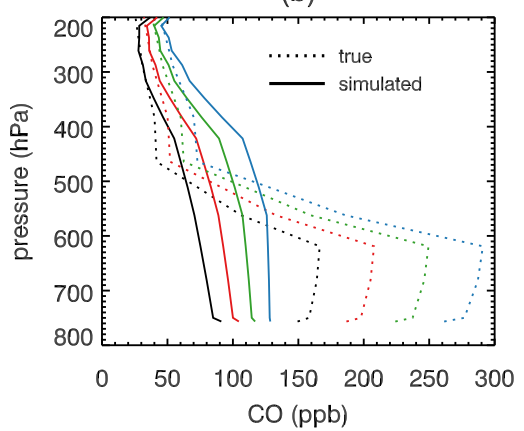

(d) TES $\mathrm{CH}_{3} \mathrm{OH}-\mathrm{CO}$

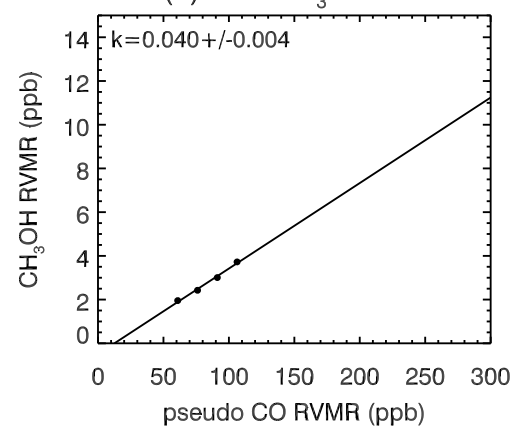

ACPD

$12,5705-5738,2012$

\section{Methanol-CO correlations in \\ Mexico City pollution outflow}

Y. Xiao et al.

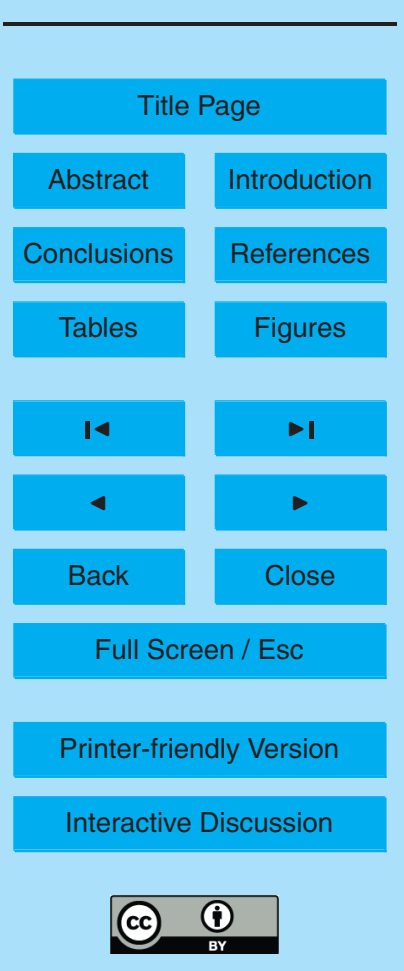

Fig. 5. Demonstration of the ability of TES to measure $\mathrm{CH}_{3} \mathrm{OH}-\mathrm{CO}$ enhancement ratios in the absence of systematic errors. (a) Dashed lines show representative $\mathrm{CH}_{3} \mathrm{OH}$ profiles ("true" profiles) constructed from an ensemble of MILAGRO aircraft observations, and used to generate simulated TES radiances. The solid lines show results of the TES retrievals ("simulated" profiles) generated from simulated radiances with TES measurement noise added. (b) As Fig. 5a, but for $\mathrm{CO}$. (c) The $\mathrm{CH}_{3} \mathrm{OH}-\mathrm{CO}$ correlation based on the actual input profiles (dashed lines in Fig. $5 \mathrm{a}$ and b). (d) TES derived $\mathrm{CH}_{3} \mathrm{OH}-\mathrm{CO}$ correlation based on the simulated retrievals (solid lines in Fig. $5 a$ and $b$ ). 

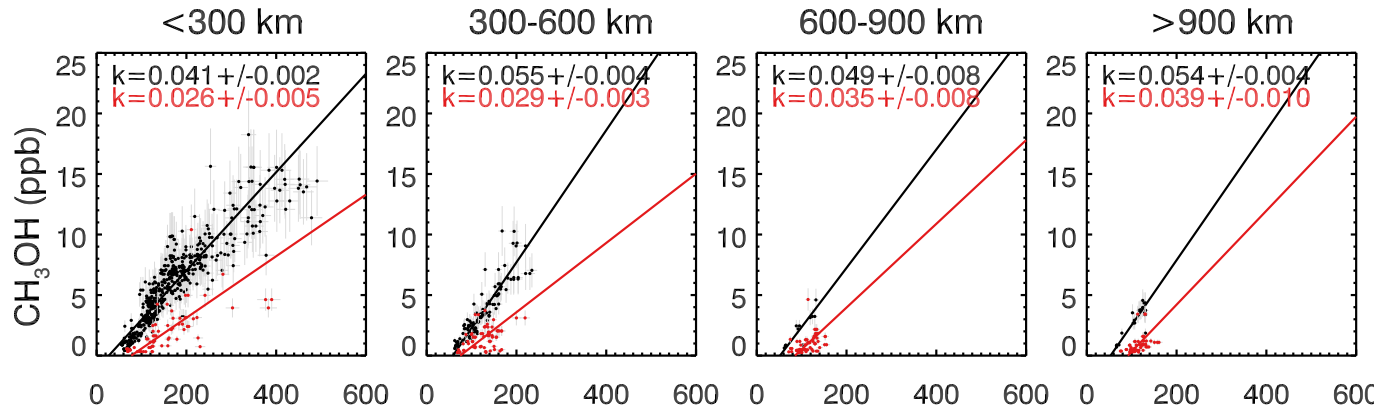
$\mathrm{CO}(\mathrm{ppb})$
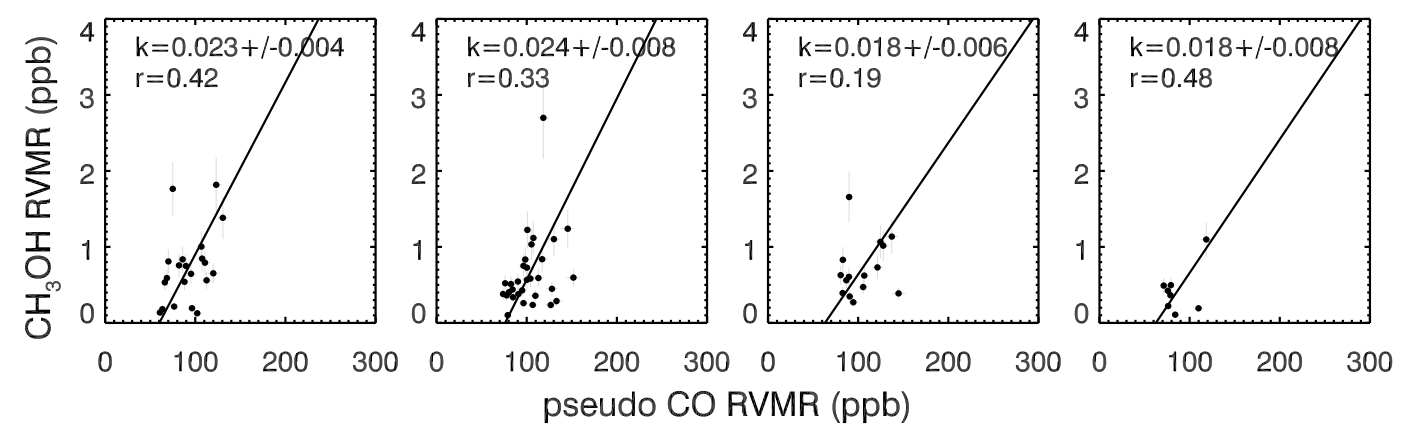

Fig. 6. $\mathrm{CH}_{3} \mathrm{OH}-\mathrm{CO}$ correlations in Mexico City outflow during MILAGRO, binned by distance from Mexico City Center. Upper panels show aircraft measurements (black for C-130 and red for DC-8). Lower panels show TES measurements.

\section{ACPD}

$12,5705-5738,2012$

\section{Methanol-CO correlations in \\ Mexico City pollution outflow}

Y. Xiao et al.

\section{Title Page}

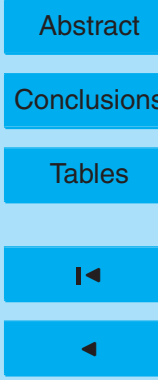

Introduction

References

\section{Figures}

$>1$

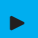

Back

Close

\section{Full Screen / Esc}

Printer-friendly Version

Interactive Discussion 


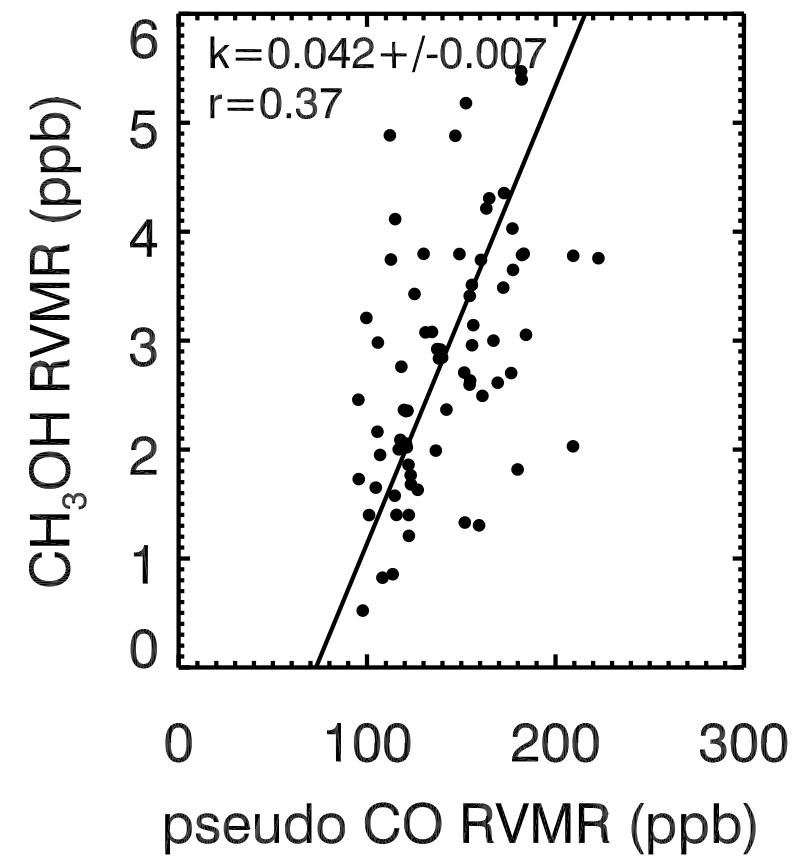

Fig. 7. $\mathrm{CH}_{3} \mathrm{OH}-\mathrm{CO}$ correlation derived from TES observations over the Amazon Basin ( $16.7^{\circ} \mathrm{S}-$ $6.9^{\circ} \mathrm{S}, 63^{\circ} \mathrm{W}-49^{\circ} \mathrm{W}$ ) during August-September of 2005.

\section{ACPD}

12, 5705-5738, 2012

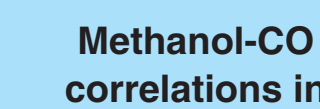

Mexico City pollution outflow

Y. Xiao et al.

Title Page

Abstract

Introduction

Conclusions

References

Tables

Figures

14

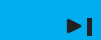

4

Back

Close

Full Screen / Esc

Printer-friendly Version

Interactive Discussion 